\title{
Cancer and HIV-1 Infection: Patterns of Chronic Antigen Exposure
}

\author{
Selena Vigano ${ }^{1}$, Sara Bobisse ${ }^{1}$, George Coukos ${ }^{1}$, Matthieu Perreau ${ }^{2}$ and \\ Alexandre Harari ${ }^{1 *}$ \\ ${ }^{1}$ Ludwig Institute for Cancer Research, University of Lausanne and Department of Oncology, University Hospital of Lausanne, \\ Lausanne, Switzerland, ${ }^{2}$ Service of Immunology and Allergy, University Hospital of Lausanne, Lausanne, Switzerland
}

\section{OPEN ACCESS}

Edited by:

Alejandra Pera

Universidad de Córdoba, Spain

Reviewed by:

Vijayakumar Velu,

Emory University, United States

Tara Marlene Strutt,

University of Central Florida,

United States

Christoph Neumann-Haefelin

University of Freiburg, Germany

*Correspondence:

Alexandre Harari

alexandre.harari@chuv.ch

Specialty section: This article was submitted to Immunological Memory, a section of the journal

Frontiers in Immunology

Received: 09 February 2020 Accepted: 27 May 2020

Published: 30 June 2020

Citation:

Vigano S, Bobisse S, Coukos G, Perreau M and Harari A (2020) Cancer and HIV-1 Infection: Patterns of Chronic Antigen Exposure.

Front. Immunol. 11:1350

doi: 10.3389/fimmu.2020.01350
The main role of the human immune system is to eliminate cells presenting foreign antigens and abnormal patterns, while maintaining self-tolerance. However, when facing highly variable pathogens or antigens very similar to self-antigens, this system can fail in completely eliminating the anomalies, leading to the establishment of chronic pathologies. Prototypical examples of immune system defeat are cancer and Human Immunodeficiency Virus-1 (HIV-1) infection. In both conditions, the immune system is persistently exposed to antigens leading to systemic inflammation, lack of generation of long-term memory and exhaustion of effector cells. This triggers a negative feedback loop where effector cells are unable to resolve the pathology and cannot be replaced due to the lack of a pool of undifferentiated, self-renewing memory T cells. In addition, in an attempt to reduce tissue damage due to chronic inflammation, antigen presenting cells and myeloid components of the immune system activate systemic regulatory and tolerogenic programs. Beside these homologies shared between cancer and HIV-1 infection, the immune system can be shaped differently depending on the type and distribution of the eliciting antigens with ultimate consequences at the phenotypic and functional level of immune exhaustion. T cell differentiation, functionality, cytotoxic potential and proliferation reserve, immune-cell polarization, upregulation of negative regulators (immune checkpoint molecules) are indeed directly linked to the quantitative and qualitative differences in priming and recalling conditions. Better understanding of distinct mechanisms and functional consequences underlying disease-specific immune cell dysfunction will contribute to further improve and personalize immunotherapy. In the present review, we describe relevant players of immune cell exhaustion in cancer and HIV-1 infection, and enumerate the best-defined hallmarks of $\mathrm{T}$ cell dysfunction. Moreover, we highlight shared and divergent aspects of $T$ cell exhaustion and $T$ cell activation to the best of current knowledge.

Keywords: HIV infection, cancer, lymphocytes, cellular immunity, exhaustion, senescence, anergy, immune checkpoint

\section{INTRODUCTION}

The primary function of the human immune system is to protect the host by reacting upon the encounter of foreign antigens, as well as to prevent autoimmunity through self-recognition. Two arms orchestrate the activation of the immune system: the innate response triggered within the first hours and the adaptive response mounted over the following days, able to recognize and target 
specific antigens and to generate memory. T cells are the major component of the adaptive immune system consisting of CD4 and CD8 T cells (1), being the latter key players in the physical elimination of tumor and virus-infected cells.

Most naïve $\mathrm{T}$ cells encounter their targets, presented by professional antigen presenting cells (i.e., dendritic cells, DCs), in secondary lymphoid organs (2). Such priming is crucial for determining the acquisition of functional attributes by $\mathrm{T}$ cells $(3,4)$. DCs govern the nature of primed T cells via the provision of processed antigens in the form of peptide/MHC complexes (signal I) and other important signals, including costimulatory interactions (signal II) and inflammatory cytokines (signal III) (5). Once activated, T cells undergo massive clonal expansion, differentiate into potent effectors, and express chemokines and homing receptors necessary for migration into peripheral tissues. Effector CD4 T cells produce several cytokines depending on the polarization determined by the cognate antigen and the extracellular milieu, effector CD8 T cells express cytotoxic molecules, such as perforin and granzymes, and produce effector cytokines. The production of cytotoxic molecules and cytokines is needed to help contain the spread of pathogens and tumors. The fate of naïve CD8 T cell differentiation is also determined by interdependent variables such as frequency of contact with the immunological synapses, epitope antigenicity, $\mathrm{T}$ cell receptor (TCR) affinity for cognate targets and the presence of CD4 T cell help (6). After CD8 T cell expansion and antigen elimination, any further immune activation is prevented by the upregulation and engagement of co-inhibitory molecules such as Cytotoxic T Lymphocyte Antigen-4 (CTLA-4) and Programmed Death1 (PD-1). Most effector $\mathrm{T}$ cells die by apoptosis (contraction phase), but about $5-10 \%$ survive and differentiate into memory $\mathrm{T}$ cells. Different theories for memory $\mathrm{T}$ cell development have been suggested (7), but recent findings strongly suggest that longlived memory CD8 T cells would arise from a subset of effector $\mathrm{T}$ cells through a process of dedifferentiation (8). Memory $\mathrm{T}$ cells are then maintained in the absence of antigens (homeostatic expansion) and can exert rapid effector functions in response to previously encountered antigens $(1,9)$.

Any disturbance of conventional activation signals may drive $\mathrm{T}$ lymphocytes to alternative cell fates, i.e., anergy, tolerance and exhaustion. This plasticity has evolved to constrain autoimmunity and excessive immune responses that would otherwise cause undesired tissue damage and immune-pathological conditions. Whereas, anergy is established during priming, due to the absence of costimulatory signals, and senescence is defined as growth arrest after extensive proliferation, exhausted $\mathrm{T}$ cells arise from cells which initially gained effector functions but became gradually dysfunctional due to continuous TCR stimulation by persistent antigens (10). Overlapping and discriminating functional and molecular features of these alternative cellular conditions have been comprehensively investigated $(11,12)$. In the present review, we describe the establishment and hallmarks of $\mathrm{T}$ cell exhaustion in HIV-1 infection and cancer. In addition, we highlight the parameters that allow the discrimination between functionally distinct $\mathrm{T}$ cell states, which are exhausted, activated, and memory $\mathrm{T}$ cells.

\section{EMERGENCE OF T CELL EXHAUSTION}

$\mathrm{T}$ cell exhaustion was initially described in the mouse model of LCMV infection (13-16), where, initially functional (17) and then transcriptional analyses led to the identification of PD-1 as first and main molecule associated with this status $(15,18,19)$. Afterwards, high PD-1 levels have been observed in Simian Immunodeficiency Virus (SIV) infected Rhesus Macaques $(15,20-22)$ as well as in HIV-1 infected patients (23-25) and this was related to $\mathrm{T}$ cell impaired function and disease progression. In HIV-1 infection, $\mathrm{T}$ cell exhaustion is caused by antigen persistency and impaired CD4 T cell help $(26,27)$. During the acute phase of the infection, CD8 T cell responses are generated, but they are incapable of mediating complete virus clearance. HIV-1 is, indeed, endowed with a high mutation rate capacity that leads to a quick and efficient escape from immune cells $(28,29)$. Moreover, lymphoid follicles have been shown to be enriched in HIV-1/SIV-infected CD4 cells, and poorly infiltrated by CD8 T cells during early SIV infection. Consistently, the frequency of SIV-specific CD8 T cells entering the lymphoid follicles is inversely associated with the levels of infected cells, suggesting a new mechanism of viral persistency (30). While infected cells are not eradicated, $\mathrm{T}$ cells are continuously exposed to viral antigens, leading to a permanent expression of negative receptors and consequently to $\mathrm{T}$ cell dysfunction $(15,31-34)$. Of note, beside antigen escape, HIV-1 preferentially infects HIV-1-specific CD4 T cells (35), leading to profound consequences in the immune-pathogenesis of the disease (28). HIV-1-specific CD4 T cells expand at high frequency during the early phase of the infection. Later on, their number decreases in blood and secondary lymphoid organs (36), due to killing by HIV-1-specific CD8 T cells, virus cytopathic effects and pyroptosis triggered by abortive viral infection (37). In an early stage, CD8 T cell responses are also quickly impaired $(27,38-40)$, nevertheless this loss of function is partially restored in the presence of HIV-1 specific CD4 T cells $(13,27)$, highlighting the importance of CD4 T cell depletion in determining CD8 T cell exhaustion. CD4 T cells indeed provide help for CD8 $\mathrm{T}$ cells by producing supportive cytokines including interleukin (IL)-2 and IL-21, which can act directly on the responding CD8 T cells (41-48). IL-2 has a pivotal importance during priming of CD8 $\mathrm{T}$ cell response, in order to generate functional memory cells able to perform homeostatic turnover and to mount potent secondary responses (49). IL-21 instead has a major role in sustaining and expanding memory CD8 T cells $(43,44)$. In mice, CD4 T cell help has been recapitulated by $\mathrm{CD} 27$ agonism that enhanced specific CD8 T cell effector functions in response to vaccination or a viral infection (50).

Induction of $\mathrm{T}$ cell exhaustion is a common trait between HIV-1 infection and cancer (17), however key differences distinguish antiviral from anti-tumor immunity due to the pathogenesis of the two diseases (Figure 1 and Table 1). The immunogenicity of the tumor is shaped by the immune system through a process called "immunoediting," as the pivotal work of Bob Schreiber first showed 15 years ago (116). In a first phase, the adaptive and the innate immune systems 


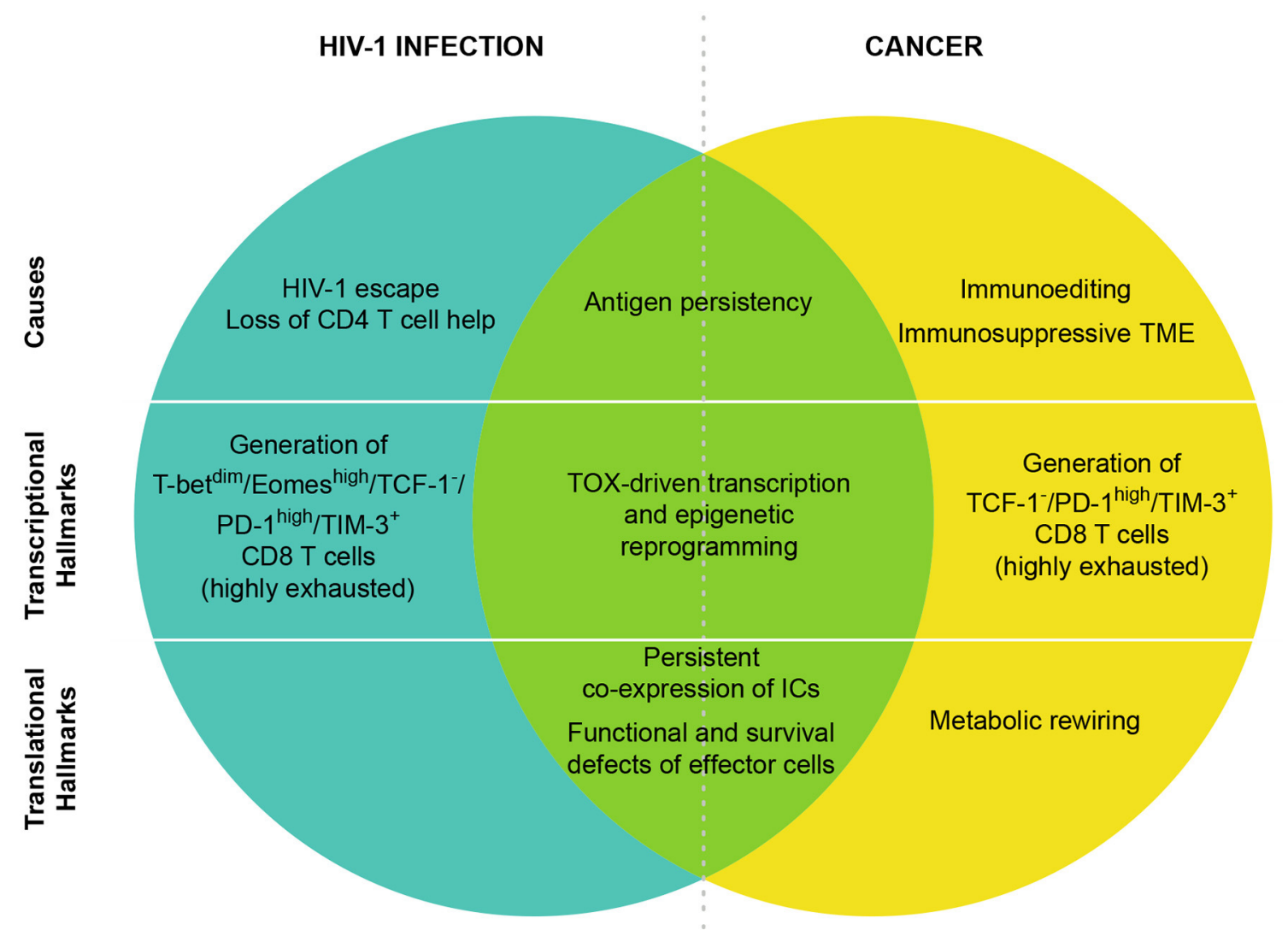

FIGURE 1 | CD8 T cell exhaustion in HIV-1 and cancer. T cell exhaustion in HIV-1 infection and cancer presents common origins and hallmarks, but also different features. The shared cause of T cell exhaustion is antigen persistency due to immune escape mechanisms. Moreover, in HIV-1 infection, the high viral mutational rate contributes to the immune escape while the preferential tropism of the virus for HIV-1 specific CD4 T cells leads to CD4 T cell loss that is also a main contributor of CD8 T cell exhaustion. In cancer, immunoediting and TME immunosuppression are peculiar determinants of tumor-specific CD8 T cell exhaustion. In both cancer and HIV-1 infection TOX has been identified as a master regulator of the transcriptional and epigenetic reprogramming of exhausted T cells. In HIV-1, T-betdim/Eomes ${ }^{\text {high }}$ subset defines highly exhausted CD8 T cells, however in CD8 T cells from cancer patients T-bet and Eomes are expressed in T cells with different levels of exhaustion. At the protein level, the co-expression of many ICs has been identified as hallmark of T cell exhaustion in both cancer and HIV-1 infection. Exhausted cells are also characterized by functional and survival defects including reduced effector functions, expansion capacity and increased susceptibility to apoptosis. Metabolic rewiring is also a key player of T cell exhaustion, however in HIV-1-infected patients little/no information is available so far.

synergize to recognize and eliminate malignant cells using conventional mechanisms (elimination phase). These include: the specific recognition of tumor-associated antigens and the expression of effector molecules by $\mathrm{T}$ lymphocytes (type I and II- interferon, perforin, Fas/FasL, tumor necrosis factor (TNF)-related apoptosis-inducing ligand-TRAIL), analogously to a viral infection, paralleled by the expression of recognition molecules such as NKG2D or ligands on tumor cells (induced by DNA damage and stress pathways) (117). Early infiltration of tumors by immune cells such as pro-inflammatory macrophages, both CD4 and CD8 T lymphocytes, NK, and DCs is crucial for tumor control (118-121). In the second phase, dormant tumor cells survive in equilibrium with the immune system where immunosuppressive and anti-tumor functions are balanced (equilibrium phase). In this phase, the tumor microenvironment (TME) is composed of several cell types that produce variable amounts of immune-suppressing and immune-stimulating molecules. In addition, tumors show a low proliferation rate and progressively undergo editing, resulting in tumor cell variants able to escape immune control (escape phase) (122). Clinically detectable tumors belong to this last and most studied phase with cancer cells proliferating with no or limited constraints. Tumor cells directly induce $\mathrm{T}$ cell exhaustion through the acquisition of somatic mutations, which confer increased immune resistance and survival, altogether contributing to prolonged antigen exposure. Ultimately, the exhaustion state is the outcome of a transcriptional and metabolic reprogramming induced by immunosuppressive cytokines (i.e., TGF- $\beta$, IL-10) and metabolites (i.e., lactate, kynurenine, adenosine, PGE2) produced by cancer cells (121, 123) and tumor infiltrating immunosuppressive cell subsets, including regulatory $\mathrm{T}$ cells, myeloid-derived suppressor cells, tumor-associated macrophages, cancer-associated fibroblasts, adipocytes, and endothelial cells (124). Moreover, anti-tumor $\mathrm{T}$ cells compete with cancer and immunosuppressive cells for nutrient availability and immunostimulatory factors. Current 
TABLE 1 | Hallmarks of exhaustion.

\begin{tabular}{|c|c|}
\hline \multicolumn{2}{|c|}{ IC expression } \\
\hline HIV-1/chronic infection & Cancer \\
\hline PD-1 (23-25) & PD-1 (51-56) \\
\hline TIM-3 $(34,58-60)$ & TIM-3 $(52,53)$ \\
\hline LAG-3 (61) & LAG-3 (53) \\
\hline TIGIT $(62,63)$ & TIGIT (64-66) \\
\hline 2B4 (CD244) $(67,68)$ & 2B4 (CD244) (70) \\
\hline BTLA (60) & BTLA (71) \\
\hline CD6 (72) & KLRG1 (73) \\
\hline & VISTA (74-76) \\
\hline & CD39 $(77,78)$ \\
\hline HIV-1/chronic infection & Cancer \\
\hline \multicolumn{2}{|c|}{ Master regulators: TOX, TCF-1 (82-85) } \\
\hline EOMES 187 (85) & STAT3 $(86,87)$ \\
\hline BLIMP-1 (88-91) & BLIMP1 $(55,92)$ \\
\hline TOX (93) & TOX $(64,93)$ \\
\hline NOTCH (94) & NR4A2 (95) \\
\hline NFATc1 (96) & NFAT (95) \\
\hline BATF $(97-100)$ & BATF (55) \\
\hline IRF4 (100) & IRF4 (85) \\
\hline VHL (101) & VHL (101) \\
\hline HIV-1/chronic infection & Cancer \\
\hline $\begin{array}{l}\text { PD-1 locus demethylation was observed in models of chronic infections (106) and in } \\
\qquad \text { HIV-1 infected patients (107) }\end{array}$ & $\begin{array}{l}\text { Tumor-reactive makers CD39 and CD103 are demethylated in tumor-reactive CD8 T } \\
\text { cells (whole-genome methylation profiling) (108) }\end{array}$ \\
\hline $\begin{array}{l}\text { Increased accessibility to Pdcd, Havcr2, and Batf loci and to loci encoding genes } \\
\text { involved in negative regulation of T cell effector functions (109) }\end{array}$ & $\begin{array}{l}\text { Recurrence after anti-PD-1 therapy was associated with the hypermethylation of the } \\
\qquad \text { PD-L1 promoter (110) }\end{array}$ \\
\hline $\begin{array}{c}\text { Recent studies show the stability of the PD-1 locus demethylation even after PD-1 } \\
\text { blockade (111) }\end{array}$ & $\begin{array}{l}\text { Two chromatin states have been identified in exhausted T cells: (i) plastic and } \\
\text { reversible, (ii) fixed dysfunctional state resistant to reprogramming (112) }\end{array}$ \\
\hline $\begin{array}{l}\text { Identification of exhaustion-specific enhancer that contains essential RAR, T-bet, and } \\
\text { Sox3 motifs (109) }\end{array}$ & $\begin{array}{c}\text { HDAC6-selective inhibitors directed peripheral and infiltrating T cells toward a } \\
\text { Th1/effector phenotype (113) }\end{array}$ \\
\hline \multicolumn{2}{|c|}{$\begin{array}{l}\text { Exhausted T cells acquire heritable de novo methylation programs able to restrict T cell expansion and clonal diversity during PD-1 blockade treatment. A } \\
\text { DNA-demethylating agent (Decitabine) improved T cell responses and tumor control during PD-1/PD-L1 blockade (114) }\end{array}$} \\
\hline 9-12 exhaustion clusters have been identified from ep & epigenomic-guided mass cytometry profiling data (115) \\
\hline
\end{tabular}

data suggest that nutrient deprivation is inducing, per se, $\mathrm{T}$ cell dysfunction (125-127).

CD8 $\mathrm{T}$ cell responses are quickly impaired during both early viral infection and tumor establishment.

Recently, terminally exhausted CD8 T cells have been characterized and distinguished from their progenitors depending upon the expression of PD-1, TIM-3, CD44, Eomes, T-bet, TCF-1, Slamf6, and CXCR5 (51, 67, 128-134). Exhausted $\mathrm{T}$ cell progenitors were characterized in LCMV models as pool of cells expressing TCF- $1^{+} / \mathrm{PD}-1^{\text {int }} / \mathrm{CXCR}^{+} / \mathrm{Slamf}^{+}$, responding to $\mathrm{PD}-1$ blockade and differentiating into terminally exhausted CD8 T cells (TCF-1 $\left.{ }^{-} / \mathrm{PD}-1^{\text {high }} / \mathrm{TIM}^{+}{ }^{+}\right)$(128-131). Their 
presence was also described among circulating tumor-reactive CD8 $\mathrm{T}$ cells in melanoma patients and within TILs in primary melanomas (135) and non-small-cell lung cancer (NSCLC) (132). Interestingly, recent studies have better characterized a subset of $\mathrm{CD} 8^{+} / \mathrm{CXCR}^{+} \mathrm{T}$ cells with proliferative capacity and able to infiltrate $\mathrm{B}$ cell follicles and inflamed tissues in the presence of chronic antigen exposure and inflammation (129, 131, 136-143). This subset shows heterogeneous phenotype and gene expression profile depending on the pathogenic context, still it is distinct from the CXCR5 ${ }^{-}$counterpart pool and maintain cytotoxic properties (144). In addition of being part of the TCF- $1^{+} / \mathrm{PD}-1^{\text {int }}$ progenitor pool $(129,145)$, these cells have been described as having variable levels of exhaustion and being similar to Tfh cells $(20,108,129,131,141,146-149)$. This is reflected in their capacity to help in the control of viral infection and of tumor growth, in the promotion of inflammation and in the induction of $\mathrm{B}$ cell responses $(108,136,137,144)$. The formation and maintenance of the TCF- $1^{+} / \mathrm{PD}-1^{\text {int }}$ progenitor pool is orchestrated by the thymocyte selection-associated high mobility group box protein TOX. While TOX is a key player in the establishment of the exhausted state, its role is largely dispensable for the generation of effector and memory $\mathrm{T}$ cells. Antigen persistency is likely to be the cause of Tox induction since its expression is dependent on calcineurin and NFAT2. TOX is therefore the translator of persistent stimulation into a distinct $\mathrm{T}$ cell transcriptional and epigenetic developmental program leading to $\mathrm{T}$ cell exhaustion. TOX is also important for the subsequent differentiation into terminally exhausted cells that is counteracted and regulated by the phosphatase PTPN2 (82-84, 150-152). PTPN2 abrogation increases the number of terminally differentiated cytotoxic CD8 $\mathrm{T}$ cells promoting effective immune response, tumor/viral clearance and improved response to inhibitory molecules blockade (84). TOX induces genes that are important for the exhaustion precursor formation, including transcription factors (TFs) (e.g., Tcf7, Nr4a2, and Tox itself) and co-inhibitory receptors (e.g., Pdcd1, Lag3, CD244, and Havcr2). In conclusion, persistent activation and induction of TOX are common drivers of T cell exhaustion in both viral infection and tumor pathogenesis. However, specific players such as CD4 T cell loss and TME heterogeneity in infection and cancer, respectively, contribute to define distinct and overlapping traits of exhausted T cells in the two conditions.

\section{HALLMARKS OF T CELL EXHAUSTION IN HIV-1 INFECTION}

Many studies have indicated HIV-1-induced T cell exhaustion as main hallmark of the disease. Of note, HIV-1-specific CD8 T cells selectively show features of exhaustion as compared to bulk CD8 T cell populations and unrelated virus-specific T cells circulating in the same subject, as described in human and animal studies (153-155).

\section{Expression of Multiple ICs}

A complex network of stimulatory and inhibitory surface molecules orchestrates the functionality of CD8 T cells $(156,157)$.
A cardinal feature of exhausted T cells in HIV-1 infection is the sustained expression of multiple inhibitory immune checkpoints (ICs) (Table 1).

The first and, to date, the most important IC involved in CD8 $\mathrm{T}$ cell exhaustion in chronic infections $(15,23-25,52,158)$ is PD-1. During chronic stimulation, PD-1 expression on virusspecific CD8 T cells is high and sustained $(23-25,68)$ because of mechanisms involving both TFs [i.e., T-bet (159), Blimp-1 $(88,160)]$ and soluble factors [i.e., IFN- $\alpha(161)$ and RANTES (156)]. In turn, PD-1 signaling affects the function, proliferation, survival and chemotaxis of CD8 T cells $(23-25,156,162)$. In vivo, PD- $1^{\text {high }}$ SIV-specific CD8 T cells are characterized by a higher turnover (163).

The interaction of PD-1 with its two ligands PD-L1 and PD-L2 on hematopoietic and non-hematopoietic cells triggers the phosphorylation of two cytoplasmic domains and the subsequent recruitment of cytosolic tyrosine phosphatases Shp2 and Shp1, the TCR-phosphorylating kinase Lck, and the inhibitory tyrosine kinase Csk $(164,165)$. These effectors mainly act by antagonizing the CD28 costimulatory signaling (166-168) and the TCR signaling via dephosphorylation of SLP76 and ZAP70 (164, 166). Moreover, signaling molecules including ERK, Vav, PLC $\gamma$, PI3K, and Ras have been described as downstream targets of PD-1 signaling in T cells, leading to an impairment in metabolism, survival and cell growth (10, $165,168,169)$. PD-1 is also expressed by CXCR5 ${ }^{+}$CD8 $\mathrm{T}$ cells $(20,170)$, a population particularly interesting for therapeutic purposes.

In addition, landmark studies in LCMV (67) and then SIV/HIV-1 infection $(33,34,62,171,172)$ highlighted the relevance of multiple ICs co-expression (i.e., CD160, 2B4, TIM3, T cell immunoreceptor with Ig and ITIM domains-TIGIT, CTLA-4 and LAG-3) to define deeply exhausted virus-specific CD8 T cells. The co-expression of multiple ICs may be due to their transcriptional co-regulation and non-redundant roles in the physiological control of CD8 T cell responses (130, 173176). Increased disease progression, viral replication and lower CD4 T cell counts were directly associated with PD-1 (23), CTLA-4 (171), TIM-3 (58, 59), LAG-3 (61), and TIGIT (62, 63) expression. In addition, the superior proliferative capacity and the maintenance of cytotoxic functions by CXCR $5{ }^{+} \mathrm{CD} 8 \mathrm{~T}$ cells concur with a lower surface expression of ICs and a higher expression of co-stimulatory receptors (CD28 and ICOS) as opposed to the $\mathrm{CXCR}^{-}$counterpart $(129,131,148)$. Of importance, SIV and HIV-1 specific CD8 T cell proliferation in vitro improves when distinct ICs (i.e. CD160, 2B4, TIGIT, BTLA, TIM-3) are blocked $(24,33,60,62)$ and administration of anti-PD-1 in SIV infected macaques (177-181) and HIV1 -infected patients (182) increases $\mathrm{T}$ cell immune responses, however clinical efficacy remains controversial (181, 183190).

More recently, in SIV-infected macaques, the expression of CD6 by $\mathrm{PD}-1^{+} \mathrm{CD} 8 \mathrm{~T}$ cells was associated with a reduced proliferation, cytokine secretion and cytotoxic capacity when compared to their $\mathrm{CD}^{-}$counterpart. The frequency of $\mathrm{CD}^{+}{ }^{+} \mathrm{PD}-1^{+} \mathrm{CD} 8 \mathrm{~T}$ cells positively correlated with SIV viral load and combined targeting of CD6 and PD-1 effectively restored the 
CD8 $\mathrm{T}$ cell proliferation capacity in vitro, suggesting that CD6 may be a new immunotherapeutic target (72).

Recently, the combination of transcriptomic and proteomic data allowed the identification of multiple cell clusters that were evolving with HIV-1 disease progression or initiation of ART (64). These data may lead to the understanding of new specific features of disease evolution and drive novel therapeutic approaches.

\section{Alteration in TFs Expression and Epigenetic Regulation}

Genomic approaches were recently applied to investigate the transcriptional profile of virus-specific exhausted CD8 T cells, revealing their unique molecular signature as compared to nonexhausted cells (Table 1) (19, 109, 111, 112, 115). Transcriptional analyses showed that exhaustion results from centrally connected pathways (19, 115, 191), having TOX as a master regulator. Indeed, TOX expression correlates with the presence of an exhausted phenotype during chronic infections in mice (LCMV) and humans (HCV) (82). In addition to TOX, several TFs coordinate gene expression networks, including PBX3, EOMES, BLIMP1 (Prdm1) (88-91), NOTCH (94), NFATc1 (96), basic leucine zipper transcription factor, ATF-like (BATF) (97-99), IRF-4, von Hippel-Lindau disease tumor suppressor (VHL), FOXO1, and FOXP1 (99-102, 130, 159, 192-198). At the molecular level, TCR stimulation leads to the induction of Tox expression (83) and induces the recruitment of TFs, like Notch (94), NFATc-1 (96), IRF-4 and BATF (100), at the promoter of different inhibitory receptors, ultimately driving their upregulation. Among the genes induced by TOX, Tcf7 (encoding TCF-1) promotes the generation of exhaustion precursors through the induction of Eomes and $c-M y b$ in early chronic infection, whereas PD-1 is needed to stabilize this pool $(85,199)$. IRF4 was also shown to favor CD8 T cell exhaustion while limiting memory $\mathrm{T}$ cell differentiation (100). Importantly, $\mathrm{PD}-1^{\text {high }} /$ Eomes ${ }^{\text {high }}$ and $\mathrm{PD}-1^{\text {low }} /$ T-bet $^{\text {high }} \mathrm{T}$ cells are both necessary to contain chronic LCMV infection (130). However, CD8 $\mathrm{T}$ cells presenting a T-bet ${ }^{\mathrm{dim}} /$ Eomes $^{\text {high }}$ profile represent a highly exhausted state with elevated levels of multiple inhibitory receptors (i.e., PD-1, CD160, and 2B4) $(200,201)$. In turn, PD1 signaling reduces the expression of $\mathrm{Bcl}-\mathrm{xl}$ (168), favoring the apoptosis of activated $\mathrm{T}$ cells $(162,202)$, and induces BATF leading to a decreased cytokine production, cytotoxic potential and proliferation rate of virus-specific CD8 T cells $(97,99)$. BATF induces the expression of T-bet and BLIMP-1 and correlates with PD-1 expression in murine models of chronic viral infection. BLIMP-1 is upregulated in patients with progressive, as opposed to non-progressive, HIV-1 infection $(194,203,204)$ and is also associated with reduced $\mathrm{T}$ cell proliferation and effector-cytokine secretion capacity; however, these functions are restored by knocking down BATF or BLIMP-1 $(88,99)$. BLIMP-1 can also be induced in T cells upon priming with HIV-1 pulsed DCs together with other inhibitory molecules, including PD-1, TIM-3, LAG-3, and CTLA-4 (205).

The characterization of the epigenetic landscape of exhausted $\mathrm{T}$ cells gives novel and key insights to decipher the function of TFs. Comprehensive whole-genome analysis of chromatin accessibility (ATAC-seq) (206), has shown that exhausted CD8 T cells have a distinct epigenetic signature $(95,109,111,112,207$, 208). For instance, exhausted CD8 T cells have several chromatin regions with reduced accessibility (e.g., the Ifng, Ccr7, Il7r, Nt5e, Tcf7, and Lef1 loci), while presenting open chromatin regions in loci that govern the expression of IC molecules (e.g., Pdcd1, Tigit, Ctla4), of ectoenzymes implicated in metabolic regulation (e.g., Cd38, Entpd1), of chemokines and cytokines (e.g., Xcl1) and of TFs (e.g., Eomes, Ikzf2, Tox) $(64,109,111)$. The deletion of chromatin accessible regions including TF binding motif for RAR-retinoic acid receptor, T-bet, and Sox3 cause a dramatic reduction in $\mathrm{PD}-1$ expression, demonstrating their important role in shaping exhausted T cell transcriptional profiling $(64,109$, 208). Moreover, during chronic LCMV infection, the $P d c d 1$ locus become completely demethylated (106), while the histone $\mathrm{H} 3$ is less diacetylated in CD8 T cells, indicating a loss in epigenetically active genes (209). In parallel, the transcriptional regulatory region of the PD-1 promoter is unmethylated in PD- ${ }^{\text {hi }} \mathrm{HIV}-1$ specific CD8 T cells but not in donor-matched naive cells (PD$\left.1^{-}\right)$(107). Thus, in chronic LCMV (106) and HIV-1 infection (107), PD-1 expression in virus-specific CD8 T cells is controlled by the chromatin accessibility of the gene itself (epigenetic control) and by TF governing its expression (Figure 2).

\section{Loss of Functions}

Exhaustion in chronic viral infections has been described in both mice and humans as the progressive decrease in the capacity of virus-specific CD8 $\mathrm{T}$ cells to secrete cytokines, proliferate and exert cytotoxicity $(23,68,210-213)$ as a consequence of persisting virus and antigen load (214). Loss of function characterizing exhaustion is hierarchical: IL-2 production is one of the first function to be extinguished, followed by TNF- $\alpha$ production, whereas the ability to produce interferon- $\gamma(\operatorname{IFN}-\gamma)$ is more resistant to inactivation $(155,213,215-218)$.

Consistently with the hierarchical loss of effector functions by exhausted T cells, Riley et al. (219) demonstrated that such effector functions depend on the strength of PD-1 signaling, thus on PD-1 expression levels.

\section{HALLMARKS OF T CELL EXHAUSTION IN CANCER}

The identification of exhausted $\mathrm{T}$ cells in the cancer setting was inspired by previous knowledge gained in chronic viral infections. In human melanoma metastasis, $\mathrm{T}$ cells sharing many features of the exhaustion signature identified in LCMV infection were found (53). However, as discussed above, the establishment of exhaustion occurs differently in viral infection and cancer, the latter involving a complex network of players and mediators. The repertoire of tumor-specific T lymphocytes is generally devoid of highly avid autoreactive cells due to central and peripheral tolerance mechanisms, and priming may be inefficient due to the lack of co-stimulation, an inflammatory milieu and/or the presence of immunoregulatory cellular subsets (220). Therefore, a more heterogeneous pool of cells, fully 


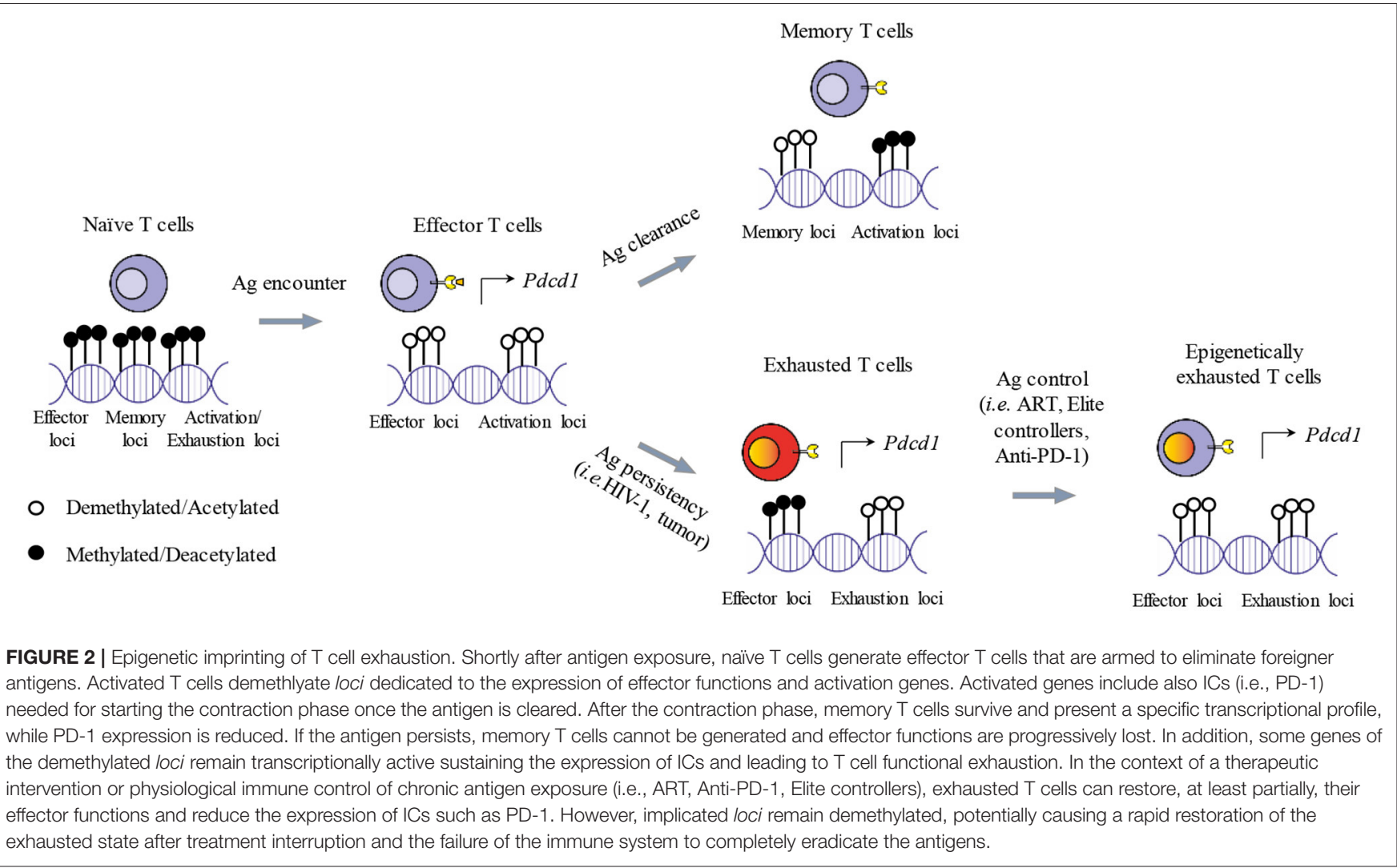

activated or not, may undergo the dysfunctional program. Consistently with their virus-specific counterparts, these cells are characterized by increased expression of ICs $(19,64$, 221), impaired homeostatic response to cytokines (222) and altered epigenetic and transcriptional programs (10, 191, 223). In contrast to HIV-1 infection where little/no information is available to date, the rewiring of the $\mathrm{T}$ cell metabolism in cancer immunopathogenesis is a well-characterized hallmark of exhaustion $(224,225)$. Of note, PD-L1 engaged by PD-1 acts as an anti-apoptotic molecule and increases chemoresistance on cancer cells through phosphorylation and activation of the PI3K/AKT pathway, as opposed to inactivation in T cells (226228). Notwithstanding the recent burst of investigations on $T$ cell exhaustion in cancer, studies in human remain challenging and animal models should be tuned to better reflect the slow course of natural cancer progression and its antigenic contexts (high/low mutational load).

\section{Expression of Multiple ICs}

In line with what is described for HIV-1 infection, a high and sustained expression of ICs is consensually considered as the main hallmark of $\mathrm{T}$ cell exhaustion in the cancer setting (Table 1). Tumor-specific CD8 TILs express high levels of PD1 associated to impaired function (54). PD-1 is expressed upon TCR engagement and NFAT nuclear translocation (96) and may drive exhaustion of $\mathrm{T}$ cells undergoing persistent antigen exposure $(18,229)$. Exhausted T cells can co-express PD-1 together with different ICs, including, LAG-3, CTLA4, BTLA, TIGIT, 2B4 (CD244), VISTA, KLRG1 (53, 73, 230) and TIM-3 $(52,131,199)$. Inhibitory receptors signal through non-overlapping pathways and use different mechanisms to regulate $\mathrm{T}$ cell function ultimately inducing exhaustion: they sequester target receptors and ligands involved in activation pathways (ectodomain competition), they dampen the signals from activating receptors and they mediate transcription of inhibitory genes (10). Importantly, the hierarchical co-expression of multiple inhibitory receptors has been associated with a more severe grade of cellular dysfunction (231). Additional, recently identified markers of CD8 T cell exhaustion in cancer include: CD39 (77, 78), LAYN, whose expression is mutually exclusive with LAG-3 in hepatocellular carcinoma patients (80), and CXCL13 (53, 79). Moreover, Stanczak et al. (81) described the Sia-SAMP:Siglec-9 as an inhibitory pathway in NSCLC, where high frequencies of Siglec $9^{+} \mathrm{CD} 8^{+}$TILs inversely correlate with survival (81). Finally, CD160 ${ }^{+}$CD8 T cells have been shown to express higher PD-1 levels than the $\mathrm{CD} 160^{-}$counterpart, to have less proliferative and cytotoxic potential and to be enriched among CD8 TILs in pancreatic cancer patients (69). Recently, a CXCR5 ${ }^{+}$CD8 $\mathrm{T}$ cell population has been observed to expand in diffuse large B cell lymphoma (232), follicular lymphoma (144) and HBV-related hepatocellular carcinoma $(137,139,141,149)$. Circulating, tumor infiltrating, and lymphoid CXCR5 ${ }^{+}$CD8 T 
cells were shown to co-express PD-1 and, in contrast with chronic viral infection $(129,131,134,148)$, TIM-3 (134, 140), however they were functionally less exhausted than the CXCR5 ${ }^{-}$CD8 T cell population and expressed genes related to stem-like plasticity and cytotoxicity $(140,141,149)$. The frequency of this subset was correlated with a better prognosis in follicular lymphoma (144), pancreatic (139), colorectal $(137,141)$, and lung (140) cancer, suggesting its anti-tumor activity. However, combined blockade of TIM-3, PD-1 or IL-10R pathways could increase the cytotoxic activity of $\mathrm{CXCR} 5^{+} \mathrm{CD} 8 \mathrm{~T}$ cells indicating their limited lytic potential $(139,149)$.

\section{Alteration in TFs Expression and Epigenetic Regulation}

Tumor cells, together with immune and non-immune populations of the TME, contribute to a well-defined gene expression profile of dysfunctional anti-tumor T cells (Table 1), partially overlapping with that of exhausted $\mathrm{T}$ cells in chronic infections, by releasing molecules and establishing inhibitory contacts. In addition, recent studies in murine and human cancer suggest that TILs display a broad spectrum of dysfunctional states shaped by the multifaceted suppressive signals that occur within the TME $(64,130,135)$. Several signaling pathways through the TCR, suppressive cytokines (TGF- $\beta$, IL-6), inhibitory receptors, metabolites (adenosine, prostaglandins, lactate), enzymes (e.g., nitric oxide synthase, reactive oxygen species, indoleamine-2,3 dioxygenase), low $\mathrm{pH}$, hypoxia and nutrient deprivation, lead to the final transactivation of TFs controlling the expression of different gene sets $(101,104,173,233,234)$. As described for chronic infections, a complex pattern of TFs drives the initial triggering of differentiation toward the exhausted phenotype, including TOX, NFAT, Blimp-1, BATF, FoxO1, VHL, IRF4 (93, 234), Bcl-6, cMAF, and STAT3 (86, 87, 104, 235, 236). These factors exert distinct roles in $\mathrm{T}$ cells at different stages of differentiation and they do not exclusively govern gene expression in exhausted $\mathrm{T}$ cells. The epigenomes of different $\mathrm{T}$ cell subsets contribute to the context-specific functions of shared TFs. For instance, STAT3 dependent transcriptional regulation limits both TILs recruitment and cytotoxic function by downregulating IFN- $\gamma$, CXCR3, and CXCL10 expression and inducing ROR- $\gamma \mathrm{t}(87,236)$. Of note, EOMES and T-bet are expressed during the whole course of tumor progression and, in contrast to chronic viral infections, they do not help in distinguishing an exhausted-progenitor subset from terminally differentiated exhausted $\mathrm{T}$ cells (Figure 1) (10, 55). More recently, new technological advances (i.e., mass cytometry and single cell sequencing) are allowing a deeper examination of the molecular properties of dysfunctional $\mathrm{T}$ cells at the single cell level. These studies represent milestones for the comprehension of $\mathrm{T}$ cell biology in the context of complex TME, dominated by a high heterogeneity of cellular subsets. Recently, Bengsch et al. $(64,115)$ identified 9 distinct $\mathrm{T}$ cell clusters among exhausted CD8 T cells in HIV-1 infection and human lung cancer by using transcriptomic- and epigeneticguided mass cytometry. This study also assigned an exhaustion score to each of the subsets based on functional features
$(64,115)$, those providing relevant insight for the design of IC blockade therapies.

\section{Loss of Functions}

As in chronic viral infections, exhausted $\mathrm{T}$ cells found in different tumor types have reduced effector functions as shown in terms of cytokine production and cytotoxicity $(53,237)$. Nevertheless, the hierarchy by which $\mathrm{T}$ cells progressively lose their functions is less clear $(53,54,231,237-239)$. TILs are not functionally inert and, to some extent, contribute to tumor control $(231,240)$. The efficacy of IC inhibitors and IL-2-driven ex vivo expansion of functional TILs is an indirect proof of this impaired yet present anti-tumor activity. Furthermore, TILs can be highly heterogeneous among distinct cancer types as evidenced by their different capacity to respond to IC blockade. For instance, in small-cell lung cancer patients, subsets of PD$1^{\text {high }}$ TILs are enriched in tumor-specific $\mathrm{T}$ cells and their presence is a predictor of clinical response to anti-PD-1 therapy (132, 241-243). On the contrary, T cells infiltrating breast tumor retain robust cytokine production and degranulation capacity (244) notwithstanding the expression of PD-1. In breast cancer patients, PD-1 expression is therefore less predictive of TILs dysfunction and this may explain the modest clinical responses to anti-PD-1 or anti-PDL therapies.

The proliferative potential of exhausted T cells is considered limited due to unresponsiveness to homeostatic cytokines such as IL-7, IL-15 and IL-21 $(211,245,246)$. However, the previously mentioned $\mathrm{TCF}-1^{+} / \mathrm{PD}-1^{\text {int }}$ progenitor pool of exhausted $\mathrm{T}$ cells has a residual proliferative potential that allows the replenishment of the pool of exhausted antigen-specific CD8 T cells by expanding and differentiating into the numerically larger population of TCF- $1^{-} / \mathrm{PD}-1^{\text {hi }} / \mathrm{TIM}-3^{+}$terminal progeny, characterized by a higher co-expression of other ICs and limited proliferative capacity $(135,199)$.

In a work by $\mathrm{Li} \mathrm{H}$. and co-workers, the intra-tumoral immune infiltrates of 25 melanoma patients differing for staging and treatments were analyzed by scRNA-seq for a deep characterization of dysfunctional $\mathrm{T}$ cells both in terms of transcriptional states and TCR clonality (238). Exhausted T cells expressing previously reported ICs (i.e., PD-1 and LAG3) were observed in many patients. Importantly, intra-tumoral CD8 T cells could cluster in two distinct subpools. $\mathrm{T}$ cells belonging to the first pool spanned a wide range of transcriptional states, from transitioning to highly dysfunctional, expressed a gradient of inhibitory molecules and were specifically observed in tumor tissue. Some of the expressed regulatory molecules (CSF1, ZBED2) were also shared with regulatory T cells. A second subpool included $\mathrm{T}$ cells with cytotoxic potential, but limited proliferative capacity. This second pool of T cells could represent bystander $\mathrm{T}$ cells, likely from the circulation. Tumor-specific $\mathrm{T}$ cells were enriched in the exhausted pool, as previously observed for NSCLC (132). Strikingly, T cells with an initial buildup of the dysfunctional program maintained a clear proliferative signal with a doubling time of few days and rapid turnover. This dynamic and active $\mathrm{T}$ cell state fits previously suggested models of establishment of exhaustion at the tumor site (238). Common mechanisms of the emergence of exhaustion are present among 
tumor types, but differences in the relative abundance of the subsets can be due to different TME, i.e., availability of antigens and exposure to inhibitory factors as well-shown for TILs in breast cancer (244). This is then reflected in the different capacity to respond to IC blokade that is not only heterogeneous among tumor types but also among individuals (244), as reviewed elsewhere (247).

In conclusion, in both HIV-1 infection and established tumors, $\mathrm{T}$ cell exhaustion is likely driven by TOX and the subsequent coordinated expression of several TFs. Exhausted $\mathrm{T}$ cells are characterized by loss of effector functions, high expression of multiple ICs, reduced homeostatic expansion, altered TFs expression, and remodeled chromatin. However, while in HIV-1 infection T-bet and EOMES allow the distinction between progenitors and fully exhausted $\mathrm{T}$ cells, in cancer patients TCF-1 and STAT3 may instead be the key TFs. The avidity and the hierarchy of the loss of function of exhausted $\mathrm{T}$ cells in cancer patients is less well-described than in chronic infections. Exhausted cells present in the TME may be highly heterogeneous and not include only the antigen-specific ones; new insights will explain how these aspects could affect the response to IC blockade.

\section{EXHAUSTED VS. ACTIVATED/MEMORY CD8 T CELLS}

Given the high heterogeneity and dynamicity of the memory CD8 T cell compartment $(64,238,248)$, novel immunotherapies, aiming at rescuing the functionality of exhausted $\mathrm{T}$ cells, would require the ability to selectively distinguish exhausted from memory and activated effector T cells.

\section{Expression of Surface Molecules}

The solely qualitative evaluation of ICs expression by CD8 T cells, per se, does not discriminate between exhausted and activated T cells. As previously mentioned, inhibitory receptors that are transiently expressed on activated effector $\mathrm{T}$ cells show a higher and sustained upregulation on exhausted $\mathrm{T}$ cells, triggered by a persistent antigen stimulation. For instance, PD-1 is rapidly upregulated upon $\mathrm{T}$ cell activation (249) and persists at moderate levels in healthy subjects with a preferential expression on effector memory T cells (162, 250253). During chronic infections, PD-1 expression on viralspecific $\mathrm{T}$ cells increases $(23,38,128,254,255)$ and does not always reverse upon antigen removal $(175,256)$. HIV-1-infected patients responding to ART show reduced expression levels of PD-1 on virus-specific CD8 T cells after antigen clearance (257), still these levels are maintained above the physiological threshold observed in healthy individuals. This may be due to a broad systemic immune activation, to the effects of common gamma-delta chain cytokines sustaining PD-1 expression on bulk CD8 T cells $(258,259)$ or to the irreversible transcriptional and epigenetic alteration affecting highly exhausted T cells $(106,260)$ (Figure 2).
As previously mentioned, the degree of exhaustion is directly associated with the pattern of co-expression of different coinhibitory receptors (67). First, this is mechanistically relevant, as simultaneous blocking of multiple ICs results in a synergistic reversal of $\mathrm{T}$ cell exhaustion in both cancer and chronic infections (171, 239, 261-263). Second, the identification of co-expression subsets may lead to a better discrimination between exhausted and activated $\mathrm{T}$ cells, reducing the risk for off-targets effects.

Many studies have shown that chronic antigen stimulation of $\mathrm{T}$ cells drives an IC expression pattern. For instance, TIM-3 and PD-1 cooperate for the induction of CD8 T cell exhaustion in cancer (52, 264-266) and chronic viral infections (34). In LCMV infection, PD-1 and TIM-3 identify a population of T cells strongly enriched in gene signatures of terminal exhaustion and harboring reduced proliferative capacity, longevity and cytokine production (64). In HIV-1 infected patients, ART significantly suppresses TIM-3 expression on HIV-1 specific CD8 T cells (267) indicating that, like PD-1, it is dependent on chronic TCR stimulation. Moreover, the expression profile of CD56 and TIM-3 can discriminate between individuals that naturally control HIV-1 replication (elite patients) and ARTtreated patients (268). After virus-clearance and CD4T cell recovery, patients receiving $\mathrm{ART}$ show a quantitative loss of CD56 ${ }^{+}$CD8 $\mathrm{T}$ cells coupled to an exhausted phenotype, as shown by TIM-3 upregulation. Elite patients maintain a pool of cytolytic $\mathrm{CD} 6^{+} \mathrm{CD} 8 \mathrm{~T}$ cells comparable to healthy individuals. Similarly, CD160 expression also allows the distinction between exhausted and activated $\left(\mathrm{PD}-1^{+}\right) \mathrm{HIV}-1$ specific CD8 T cells (33). Indeed, only cells co-expressing CD160 and PD-1 (PD- $1^{\text {high }}$ CD $160^{\text {high }}$ ) are functionally impaired in HIV-1 infected patients (33).

In cancer, the activation of ICs other than PD-1/PD-L1 and CTLA-4 can be induced by adaptive resistance to IC therapies. The treatment of such tumors could benefit from the combination of anti-PD-1 with different immune checkpoint molecules (e.g., LAG-3, TIM-3, TIGIT), activation markers and cytokines/chemokines (269). On the other hand, T cell dysfunction is characterized by decreased levels of co-stimulatory molecules, of their ligands and of adaptor molecules impairing the co-stimulatory signaling. Among these, CD44, LY6C, killer cell lectin-like receptor subfamily G member 1 (KLRG1), CD122 (IL-2R $\beta$ ), and CD127 (IL-7R), tumor necrosis factor receptor (TNFR)- associated factor 1 (TRAF1), CD28, and 41BBL have been described $(67,175,246,258,259)$. In particular, exhausted $\mathrm{T}$ cells display the same profile of effector $\mathrm{T}$ cells with reduced telomere length and low levels of CD62L, CD127, and CD122 expression $(1,40,153,215,258,270-273)$. Their incapacity to respond to IL-7 and IL-15 $(88,128,159,245)$ lead to the lack of homeostatic expansion in the absence of antigens $(1,88,128$, $130,159)$ and, ultimately, to death $(14,154,215,256,274-276)$. $\mathrm{T}$ cell dysfunction is also characterized by the downregulation of the signaling adaptor TNFR-associated factor 1 (TRAF1) both in HIV-1 infected patients with progressive disease and in LCMV chronically-infected mice (259). In HIV-1 infected patients, TRAF1 expression negatively correlates with PD-1 expression and viral load and knockdown of TRAF1 in CD8 T cells from viral controllers results in decreased HIV-1 suppression ex 
vivo. TGF- $\beta$ is responsible for the post-translational loss of TRAF1, while IL-7 signaling is able to restore TRAF1 levels. Transfer of TRAF $1^{+}$memory $\mathrm{T}$ cells or a combination treatment with IL-7 and agonist anti-4-1BB antibody in chronic LCMV infection improve $\mathrm{T}$ cell expansion and viral control in a TRAF1-dependent manner (259). Patient samples of renal cell carcinoma also show reduced expression of TRAF1 compared with normal kidney. This confers resistance to apoptosis and higher proliferative capacity to renal cancer cells (277). These findings identify TRAF1 as a potential biomarker of $\mathrm{T}$ cell dysfunction and therapeutic target. Moreover, combining PD1 blockade with an agonistic antibody to $4-1 \mathrm{BB}$ dramatically improved $\mathrm{T}$ cell function and LCMV control in vivo (278). Still, the role of positive co-stimulatory molecules in rescuing exhausted T cells remains poorly described.

\section{Transcriptional and Epigenetic Regulation}

Another key difference between exhausted and activated T cells resides in the TFs $(18,19,191,279)$. Both the quality of the expressed TFs and the genes they can target, distinguish exhausted T cells from activated and memory CD8 T cells (191, 280, 281).

Transcriptional profiling analysis demonstrated that CD8 T cell memory and exhaustion reflect distinct states defined by coordinated sets of modules. Specific genes and pathways differentially implicated in exhaustion $v s$. memory include genes involved in epigenetics, DNA damage, and WNT signaling, such as Rtp4, Foxp1, Ikzf2, Zeb2, Lass6, Tox, and Eomes (191). The study by Bengsch et al. $(64,115)$ associates effector and exhausted $\mathrm{T}$ cells to a higher expression of CD39, LAG-3, TCF-1, Helios, CTLA-4 and PD-1, Eomes, TOX, 2B4, TIGIT, respectively.

During acute infection, T-bet and EOMES play pivotal roles in the generation of terminally-differentiated $(2,282)$ and centralmemory (283-285) CD8 T cells respectively, while CD8 effector $\mathrm{T}$ cells co-express T-bet and EOMES (286). In contrast, during chronic infection, exhausted $\mathrm{T}$ cell subsets express either $\mathrm{T}$ bet or EOMES in a somehow mutually exclusive pattern and they identify pools of non-terminal progenitor and terminallydifferentiated exhausted CD8 T cells, respectively (Figure 1) (130). Of note, anti-PDL1 therapy only improves the function of the T-bet ${ }^{\text {hi }}$ subset, while having little impact on EOMES ${ }^{\text {hi }}$ cells $(128,130)$, indicating an important aspect of population dynamics in IC blockade-mediated reversal of $\mathrm{T}$ cell exhaustion. A similar population of CD8 $\mathrm{T}$ cells responding to IC blockade, $\left(\mathrm{PD} 1^{\text {int }} / \mathrm{TCF}-1^{+}\right)$, has been recently described as precursors of terminally exhausted cells (PD $\left.1^{\text {high }} / \mathrm{TCF}-1^{-} / \mathrm{TIM}-3^{+}\right)$to be distinguished from memory precursors cells $\left(\mathrm{PD} 1^{-} / \mathrm{TCF}^{-}{ }^{+}\right)$on the basis of several epigenetic and transcriptional alterations such as higher expression of CXCR5 and Slamf6 (199).

By using a combined experimental and computational approach, Singer et al. (105) described mutually exclusive gene modules to distinguish dysfunctional from activated $\mathrm{T}$ cells in a murine colon carcinoma model. In particular, metallothionins, responsible for regulating the intracellular zinc metabolism, and zinc-dependent TFs were found to be highly enriched in dysfunctional CD8 TILs. GATA-3, a zinc-finger TF, consistently emerged as a driver of $\mathrm{T}$ cell dysfunction. Moreover, the expression of the co-inhibitory receptors PD-1 and TIM-3 was maintained upon metallothion-deletion, being uncoupled from the gene dysfunctional module (105).

Epigenetic studies also helped in identifying patterns distinguishing $\mathrm{T}$ cell exhaustion from $\mathrm{T}$ cell activation/memory profile. Recent epigenetic studies in mice and humans indicate that exhausted $\mathrm{T}$ cells represent a unique $\mathrm{T}$ cell lineage, compared to effector and memory $\mathrm{T}$ cells and are a stable, distinct and disease-relevant cell type $(109,111,112)$.

HIV-1- and HCV-specific CD8 T cell genomes present a high accessibility to exhaustion-associated nucleotide regions. On the opposite, the genome of CMV-specific CD8 T cells is characterized by a higher accessibility to memory-specific nucleotide regions (109). Interestingly, the accessibility to exhaustion-specific regions is reduced in CD8 T cells specific for HCV epitopes that undergo viral escape (109), indicating that chronic exposure is needed to shape exhaustion-associated epigenetic imprinting.

Studies focusing on $P d c d 1$ locus revealed that during the effector phase of an acute LCMV infection, the promoter regions were largely demethylated to become remethylated as the infection solved and CD8 T cell memory formed $(106,287)$. In the context of a chronic LCMV infection, the demethylation observed in the Pdcd1 locus during chronic LCMV infection was instead stable and no remethylation was observed, even when viral titers and PD-1 protein expression by exhausted CD8 T cells decreased (106) or after transfer in recipient mice (260). Along the same lines, the unmethylated state of the Pdcd1 locus did not change in $\mathrm{T}$ cells from subjects with a viral load controlled by ART for several years or from elite controllers (107). This suggests that the epigenetic program of the PD1 locus is stabilized after prolonged exposure to HIV-1 virus despite different levels of PD-1 surface expression. Consistently, the transcriptome and the epigenome of terminally exhausted CD8 T cells (PD-1 $1^{\text {high }} / \mathrm{TCF}-1^{-} / \mathrm{TIM}_{-} 3^{+}$) are stably rewired and resistant to remodeling after PD-1 blockade $(111,114)$ (Figure 2).

These data strongly suggest that epigenetic remodeling may be required to further improve strength and breadth of the efficacy of immune checkpoint blockade.

In conclusion, exhausted $\mathrm{T}$ cells can be distinguished from activated $\mathrm{T}$ cells by the higher and sustained co-expression of IC molecules, as well as by a phenotype skewed toward effector memory cells with reduced co-stimulatory molecules expression. Moreover, the systemically induced immune activation and the stable transcriptional and epigenetic imprinting established during $\mathrm{T}$ cell exhaustion do not allow the restoration of IC molecules expression to the levels measured in healthy donors even after antigen removal/reduction. Among the TFs analyzed, T-bet, and EOMES allow the distinction between activated and exhausted CD8 T cells in HIV-1 infection, while metallothionins and GATA-3 have been suggested as discriminators in cancer patients.

\section{CONCLUSIONS}

Recent major advances in immunotherapy ultimately demonstrated the potentiality of the immune system in disease control. However, they also proved that existing strategies are hampered by the immune tolerance established by IC expression 
on $\mathrm{T}$ cells. In addition, despite the significant difference in the availability of clinical information concerning immunotherapy efficacy in cancer and HIV-1 infection, there is still a long way to go for the scientific community to decipher the mechanisms of immunosuppression in different indications. Recently, new technological advances (such as mass cytometry, single cell sequencing, ATAseq, metabolomics) are allowing a deeper examination of the molecular properties of dysfunctional $\mathrm{T}$ cells at the single cell level. These studies represent milestones for the comprehension of $\mathrm{T}$ cell biology in the context of complex TME, dominated by a high heterogeneity of cellular subsets and in HIV-1 infection where current immunotherapy may not improve $\mathrm{T}$ cell responses $(64,115)$. These data may lead to the understanding of new specific features of disease evolution and drive novel immunotherapeutic approaches.

\section{REFERENCES}

1. Wherry EJ, Ahmed R. Memory CD8 T-cell differentiation during viral infection. J Virol. (2004) 78:5535-45. doi: 10.1128/JVI.78.11.5535-554 5.2004

2. Kaech SM, Cui W. Transcriptional control of effector and memory CD8+ T cell differentiation. Nat Rev Immunol. (2012) 12:749-61. doi: $10.1038 /$ nri3307

3. Badovinac VP, Porter BB, Harty JT. CD8+ T cell contraction is controlled by early inflammation. Nat Immunol. (2004) 5:809-17. doi: 10.1038/ni1098

4. Mercado R, Vijh S, Allen SE, Kerksiek K, Pilip IM, Pamer EG. Early programming of $\mathrm{T}$ cell populations responding to bacterial infection. $J$ Immunol. (2000) 165:6833-9. doi: 10.4049/jimmunol.165.12.6833

5. Mescher MF, Curtsinger JM, Agarwal P, Casey KA, Gerner M, Hammerbeck $\mathrm{CD}$, et al. Signals required for programming effector and memory development by CD8+ $\mathrm{T}$ cells. Immunol Rev. (2006) 211:81-92. doi: 10.1111/j.0105-2896.2006.00382.x

6. Eisenbarth SC. Dendritic cell subsets in $\mathrm{T}$ cell programming: location dictates function. Nat Rev Immunol. (2019) 19:89-103. doi: 10.1038/s41577-018-0088-1

7. Omilusik KD, Goldrath AW. The origins of memory T cells. Nature. (2017) 552:337-9. doi: 10.1038/d41586-017-08280-8

8. Youngblood B, Hale JS, Kissick HT, Ahn E, Xu X, Wieland A, et al. Effector CD8 T cells dedifferentiate into long-lived memory cells. Nature. (2017) 552:404-9. doi: 10.1038/nature25144

9. Williams MA, Bevan MJ. Effector and memory CTL differentiation. Annu Rev Immunol. (2007) 25:171-92. doi: 10.1146/annurev.immunol.25.022106.141548

10. Wherry EJ, Kurachi M. Molecular and cellular insights into T cell exhaustion. Nat Rev Immunol. (2015) 15:486-99. doi: 10.1038/nri3862

11. Delgoffe GM, Powell JD. Feeding an army: the metabolism of T cells in activation, anergy, and exhaustion. Mol Immunol. (2015) 68(2 Pt C):492-6. doi: 10.1016/j.molimm.2015.07.026

12. Schietinger A, Greenberg PD. Tolerance and exhaustion: defining mechanisms of $\mathrm{T}$ cell dysfunction. Trends Immunol. (2014) 35:51-60. doi: 10.1016/j.it.2013.10.001

13. Zajac AJ, Blattman JN, Murali-Krishna K, Sourdive DJ, Suresh M, Altman JD, et al. Viral immune evasion due to persistence of activated $\mathrm{T}$ cells without effector function. J Exp Med. (1998) 188:2205-13. doi: 10.1084/jem.188.12.2205

14. Moskophidis D, Laine E, Zinkernagel RM. Peripheral clonal deletion of antiviral memory CD8+ T cells. Eur J Immunol. (1993) 23:3306-11. doi: 10.1002/eji.1830231237

15. Barber DL, Wherry EJ, Masopust D, Zhu B, Allison JP, Sharpe AH, et al. Restoring function in exhausted CD8 T cells during chronic viral infection. Nature. (2006) 439:682-7. doi: 10.1038/nature04444

\section{AUTHOR CONTRIBUTIONS}

SV and SB wrote the manuscript. All authors contributed to the article and approved the submitted version.

\section{FUNDING}

This work was supported by the Swiss National Science Foundation (Grant 310030_182384).

\section{ACKNOWLEDGMENTS}

The authors acknowledge Mr. Samuel Cooper for his valuable proofreading of the manuscript.

16. Moskophidis D, Lechner F, Pircher H, Zinkernagel RM. Virus persistence in acutely infected immunocompetent mice by exhaustion of antiviral cytotoxic effector T cells. Nature. (1993) 362:758-61. doi: 10.1038/362758a0

17. McLane LM, Abdel-Hakeem MS, Wherry EJ. CD8 T Cell exhaustion during chronic viral infection and cancer. Annu Rev Immunol. (2019) 37:457-95. doi: 10.1146/annurev-immunol-041015-055318

18. Wherry EJ. T cell exhaustion. Nat Immunol. (2011) 12:492-9. doi: $10.1038 /$ ni.2035

19. Wherry EJ, Ha SJ, Kaech SM, Haining WN, Sarkar S, Kalia V, et al. Molecular signature of CD8+ $\mathrm{T}$ cell exhaustion during chronic viral infection. Immunity. (2007) 27:670-84. doi: 10.1016/j.immuni.2007.09.006

20. Petrovas C, Ferrando-Martinez S, Gerner MY, Casazza JP, Pegu A, Deleage C, et al. Follicular CD8 T cells accumulate in HIV infection and can kill infected cells in vitro via bispecific antibodies. Sci Transl Med. (2017) 9:eaag2285. doi: 10.1126/scitranslmed.aag2285

21. Velu V, Kannanganat S, Ibegbu C, Chennareddi L, Villinger F, Freeman GJ, et al. Elevated expression levels of inhibitory receptor programmed death 1 on simian immunodeficiency virus-specific CD8 T cells during chronic infection but not after vaccination. J Virol. (2007) 81:5819-28. doi: 10.1128/JVI.00024-07

22. Hong JJ, Amancha PK, Rogers K, Ansari AA, Villinger F. Re-evaluation of PD-1 expression by $\mathrm{T}$ cells as a marker for immune exhaustion during SIV infection. PLoS ONE. (2013) 8:e60186. doi: 10.1371/journal.pone.0060186

23. Day CL, Kaufmann DE, Kiepiela P, Brown JA, Moodley ES, Reddy S, et al. PD-1 expression on HIV-specific T cells is associated with T-cell exhaustion and disease progression. Nature. (2006) 443:350-4. doi: 10.1038/nature05115

24. Trautmann L, Janbazian L, Chomont N, Said EA, Gimmig S, Bessette $\mathrm{B}$, et al. Upregulation of PD-1 expression on HIV-specific CD8 + T cells leads to reversible immune dysfunction. Nat Med. (2006) 12:1198-202. doi: $10.1038 / \mathrm{nm} 1482$

25. Petrovas C, Casazza JP, Brenchley JM, Price DA, Gostick E, Adams WC, et al. PD-1 is a regulator of virus-specific CD8 + T cell survival in HIV infection. $J$ Exp Med. (2006) 203:2281-92. doi: 10.1084/jem.20061496

26. Rosenberg ES, Billingsley JM, Caliendo AM, Boswell SL, Sax PE, Kalams SA, et al. Vigorous HIV-1-specific CD4+ T cell responses associated with control of viremia. Science. (1997) 278:1447-50. doi: 10.1126/science.278.5342.1447

27. Lichterfeld M, Kaufmann DE, Yu XG, Mui SK, Addo MM, Johnston MN, et al. Loss of HIV-1-specific CD8 $+\mathrm{T}$ cell proliferation after acute HIV-1 infection and restoration by vaccine-induced HIV-1-specific CD4+ T cells. J Exp Med. (2004) 200:701-12. doi: 10.1084/jem.20041270

28. Pantaleo G, Fauci AS. Immunopathogenesis of HIV infection. Annu Rev Microbiol. (1996) 50:825-54. doi: 10.1146/annurev.micro.50.1.825

29. Hoffmann M, Pantazis N, Martin GE, Hickling S, Hurst J, Meyerowitz J, et al. Exhaustion of activated CD8 T cells predicts disease progression in primary HIV-1 infection. PLoS Pathog. (2016) 12:e1005661. doi: 10.1371/journal.ppat.1005661 
30. Li S, Folkvord JM, Kovacs KJ, Wagstaff RK, Mwakalundwa G, Rendahl $\mathrm{AK}$, et al. Low levels of SIV-specific CD8+ T cells in germinal centers characterizes acute SIV infection. PLoS Pathog. (2019) 15:e1007311. doi: 10.1371/journal.ppat.1007311

31. Chen Y, Zander R, Khatun A, Schauder DM, Cui W. Transcriptional and epigenetic regulation of effector and memory CD8 $\mathrm{T}$ cell differentiation. Front Immunol. (2018) 9:2826. doi: 10.3389/fimmu.2018.02826

32. Kuchroo VK, Anderson AC, Petrovas C. Coinhibitory receptors and CD8 T cell exhaustion in chronic infections. Curr Opin HIV AIDS. (2014) 9:439-45. doi: 10.1097/COH.0000000000000088

33. Peretz Y, He Z, Shi Y, Yassine-Diab B, Goulet JP, Bordi R, et al. CD160 and PD-1 co-expression on HIV-specific CD8 T cells defines a subset with advanced dysfunction. PLoS Pathog. (2012) 8:e1002840. doi: 10.1371/journal.ppat.1002840

34. Jin HT, Anderson AC, Tan WG, West EE, Ha SJ, Araki K, et al. Cooperation of Tim-3 and PD-1 in CD8 T-cell exhaustion during chronic viral infection. Proc Natl Acad Sci USA. (2010) 107:14733-8. doi: 10.1073/pnas.1009731107

35. Douek DC, Brenchley JM, Betts MR, Ambrozak DR, Hill BJ, Okamoto Y, et al. HIV preferentially infects HIV-specific CD4+ T cells. Nature. (2002) 417:95-8. doi: 10.1038/417095a

36. Brenchley JM, Schacker TW, Ruff LE, Price DA, Taylor JH, Beilman GJ, et al. CD4+ $\mathrm{T}$ cell depletion during all stages of HIV disease occurs predominantly in the gastrointestinal tract. J Exp Med. (2004) 200:749-59. doi: $10.1084 /$ jem.20040874

37. Doitsh G, Galloway NL, Geng X, Yang Z, Monroe KM, Zepeda O, et al. Cell death by pyroptosis drives CD4 T-cell depletion in HIV-1 infection. Nature. (2014) 505:509-14. doi: 10.1038/nature12940

38. Petrovas C, Price DA, Mattapallil J, Ambrozak DR, Geldmacher C, Cecchinato V, et al. SIV-specific CD8+ $\mathrm{T}$ cells express high levels of PD1 and cytokines but have impaired proliferative capacity in acute and chronic SIVmac251 infection. Blood. (2007) 110:928-36. doi: 10.1182/blood-2007-01-069112

39. Petrovas C, Mueller YM, Yang G, Altork SR, Jacobson JM, Pitsakis $\mathrm{PG}$, et al. Actin integrity is indispensable for CD95/Fas-induced apoptosis of HIV-specific CD8+ T cells. Apoptosis. (2007) 12:2175-86. doi: 10.1007/s10495-007-0128-y

40. Angelosanto JM, Blackburn SD, Crawford A, Wherry EJ. Progressive loss of memory $\mathrm{T}$ cell potential and commitment to exhaustion during chronic viral infection. J Virol. (2012) 86:8161-70. doi: 10.1128/JVI.00889-12

41. Bachmann MF, Wolint P, Walton S, Schwarz K, Oxenius A. Differential role of IL-2R signaling for CD8 $+\mathrm{T}$ cell responses in acute and chronic viral infections. Eur J Immunol. (2007) 37:1502-12. doi: 10.1002/eji.200637023

42. Castellino F, Huang AY, Altan-Bonnet G, Stoll S, Scheinecker C, Germain RN. Chemokines enhance immunity by guiding naive CD8+ T cells to sites of CD4+ T cell-dendritic cell interaction. Nature. (2006) 440:890-5. doi: 10.1038/nature04651

43. Elsaesser H, Sauer K, Brooks DG. IL-21 is required to control chronic viral infection. Science. (2009) 324:1569-72. doi: 10.1126/science.1174182

44. Frohlich A, Kisielow J, Schmitz I, Freigang S, Shamshiev AT, Weber J, et al. IL-21R on T cells is critical for sustained functionality and control of chronic viral infection. Science. (2009) 324:1576-80. doi: 10.1126/science.1172815

45. Nakanishi Y, Lu B, Gerard C, Iwasaki A. CD8 ${ }^{+}$T lymphocyte mobilization to virus-infected tissue requires CD4 ${ }^{+}$T-cell help. Nature. (2009) 462:510-3. doi: 10.1038/nature08511

46. Williams MA, Holmes BJ, Sun JC, Bevan MJ. Developing and maintaining protective CD8+ memory $\mathrm{T}$ cells. Immunol Rev. (2006) 211:146-53. doi: 10.1111/j.0105-2896.2006.00389.x

47. Williams MA, Tyznik AJ, Bevan MJ. Interleukin-2 signals during priming are required for secondary expansion of CD8+ memory T cells. Nature. (2006) 441:890-3. doi: 10.1038/nature04790

48. Yi JS, Du M, Zajac AJ. A vital role for interleukin-21 in the control of a chronic viral infection. Science. (2009) 324:1572-6. doi: 10.1126/science.1175194

49. Bevan MJ. Helping the CD8 ${ }^{+}$T-cell response. Nat Rev Immunol. (2004) 4:595-602. doi: 10.1038/nri1413

50. Ahrends T, Spanjaard A, Pilzecker B, Babala N, Bovens A, Xiao Y, et al. $\mathrm{CD}^{+} \mathrm{T}$ cell help confers a cytotoxic $\mathrm{T}$ cell effector program including coinhibitory receptor downregulation and increased tissue invasiveness. Immunity. (2017) 47:848-61.e5. doi: 10.1016/j.immuni.2017.10.009

51. Miller BC, Sen DR, Al Abosy R, Bi K, Virkud YV, LaFleur MW, et al. Subsets of exhausted CD8 ${ }^{+} \mathrm{T}$ cells differentially mediate tumor control and respond to checkpoint blockade. Nat Immunol. (2019) 20:326-36. doi: 10.1038/s41590-019-0312-6

52. Sakuishi K, Apetoh L, Sullivan JM, Blazar BR, Kuchroo VK, Anderson AC. Targeting tim-3 and PD-1 pathways to reverse $\mathrm{T}$ cell exhaustion and restore anti-tumor immunity. J Exp Med. (2010) 207:2187-94. doi: 10.1084/jem.20100643

53. Baitsch L, Baumgaertner P, Devevre E, Raghav SK, Legat A, Barba L, et al. Exhaustion of tumor-specific $\mathrm{CD}^{+} \mathrm{T}$ cells in metastases from melanoma patients. J Clin Invest. (2011) 121:2350-60. doi: 10.1172/JCI46102

54. Ahmadzadeh M, Johnson LA, Heemskerk B, Wunderlich JR, Dudley ME, White DE, et al. Tumor antigen-specific CD8 T cells infiltrating the tumor express high levels of PD-1 and are functionally impaired. Blood. (2009) 114:1537-44. doi: 10.1182/blood-2008-12-195792

55. Schietinger A, Philip M, Krisnawan VE, Chiu EY, Delrow JJ, Basom RS, et al. Tumor-specific $\mathrm{T}$ cell dysfunction is a dynamic antigen-driven differentiation program initiated early during tumorigenesis. Immunity. (2016) 45:389-401. doi: 10.1016/j.immuni.2016.07.011

56. Huang AC, Postow MA, Orlowski RJ, Mick R, Bengsch B, Manne S, et al. Tcell invigoration to tumour burden ratio associated with anti-PD-1 response. Nature. (2017) 545:60-5. doi: 10.1038/nature22079

57. Kaufmann DE, Walker BD. Programmed death-1 as a factor in immune exhaustion and activation in HIV infection. Curr Opin HIV AIDS. (2008) 3:362-7. doi: 10.1097/COH.0b013e3282f9ae8b

58. Fujita T, Burwitz BJ, Chew GM, Reed JS, Pathak R, Seger E, et al. Expansion of dysfunctional Tim-3-expressing effector memory CD8 $+\mathrm{T}$ cells during simian immunodeficiency virus infection in rhesus macaques. J Immunol. (2014) 193:5576-83. doi: 10.4049/jimmunol.1400961

59. Amancha PK, Hong JJ, Ansari AA, Villinger F. Up-regulation of Tim-3 on $\mathrm{T}$ cells during acute simian immunodeficiency virus infection and on antigen specific responders. AIDS. (2015) 29:531-6. doi: 10.1097/QAD.0000000000000589

60. Grabmeier-Pfistershammer K, Stecher C, Zettl M, Rosskopf S, Rieger A, Zlabinger GJ, et al. Antibodies targeting BTLA or TIM-3 enhance HIV-1 specific T cell responses in combination with PD-1 blockade. Clin Immunol. (2017) 183:167-73. doi: 10.1016/j.clim.2017.09.002

61. Tian X, Zhang A, Qiu C, Wang W, Yang Y, Qiu C, et al. The upregulation of LAG-3 on $\mathrm{T}$ cells defines a subpopulation with functional exhaustion and correlates with disease progression in HIV-infected subjects. J Immunol. (2015) 194:3873-82. doi: 10.4049/jimmunol.1402176

62. Chew GM, Fujita T, Webb GM, Burwitz BJ, Wu HL, Reed JS, et al. TIGIT marks exhausted $\mathrm{T}$ cells, correlates with disease progression, and serves as a target for immune restoration in HIV and SIV infection. PLoS Pathog. (2016) 12:e1005349. doi: 10.1371/journal.ppat.1005349

63. Tauriainen J, Scharf L, Frederiksen J, Naji A, Ljunggren HG, Sonnerborg A, et al. Perturbed CD8 ${ }^{+}$T cell TIGIT/CD226/PVR axis despite early initiation of antiretroviral treatment in HIV infected individuals. Sci Rep. (2017) 7:40354. doi: 10.1038/srep40354

64. Bengsch B, Ohtani T, Khan O, Setty M, Manne S, O'Brien S, et al. Epigenomic-guided mass cytometry profiling reveals disease-specific features of exhausted CD8 T cells. Immunity. (2018) 48:1029-45.e5. doi: 10.1016/j.immuni.2018.04.026

65. Johnston RJ, Comps-Agrar L, Hackney J, Yu X, Huseni M, Yang Y, et al. The immunoreceptor TIGIT regulates antitumor and antiviral $\mathrm{CD}^{+} \mathrm{T}$ cell effector function. Cancer Cell. (2014) 26:923-37. doi: 10.1016/j.ccell.2014.10.018

66. Wu L, Mao L, Liu JF, Chen L, Yu GT, Yang LL, et al. Blockade of TIGIT/CD155 signaling reverses T-cell exhaustion and enhances antitumor capability in head and neck squamous cell carcinoma. Cancer Immunol Res. (2019) 7:1700-13. doi: 10.1158/2326-6066.CIR-18-0725

67. Blackburn SD, Shin H, Haining WN, Zou T, Workman CJ, Polley A, et al. Coregulation of CD8+ $\mathrm{T}$ cell exhaustion by multiple inhibitory receptors during chronic viral infection. Nat Immunol. (2009) 10:29-37. doi: 10.1038/ni.1679 
68. Vigano S, Bellutti Enders F, Miconnet I, Cellerai C, Savoye AL, Rozot V, et al. Rapid perturbation in viremia levels drives increases in functional avidity of HIV-specific CD8 T cells. PLoS Pathog. (2013) 9:e1003423. doi: 10.1371/journal.ppat.1003423

69. Liu S, Zhang W, Liu K, Wang Y. CD160 expression on $\mathrm{CD}^{+}{ }^{+} \mathrm{T}$ cells is associated with active effector responses but limited activation potential in pancreatic cancer. Cancer Immunol Immunother. (2020) 69:789-97. doi: 10.1007/s00262-020-02500-3

70. Agresta L, Hoebe KHN, Janssen EM. The emerging role of CD244 signaling in immune cells of the tumor microenvironment. Front Immunol. (2018) 9:2809. doi: 10.3389/fimmu.2018.02809

71. Fourcade J, Sun Z, Pagliano O, Guillaume P, Luescher IF, Sander $\mathrm{C}$, et al. $\mathrm{CD}^{+} \mathrm{T}$ cells specific for tumor antigens can be rendered dysfunctional by the tumor microenvironment through upregulation of the inhibitory receptors BTLA and PD-1. Cancer Res. (2012) 72:887-96. doi: 10.1158/0008-5472.CAN-11-2637

72. Enyindah-Asonye G, Nwankwo A, Rahman MA, Hunegnaw R, Hogge C, Helmold Hait S, et al. Overexpression of CD6 and PD-1 identifies dysfunctional $\mathrm{CD}^{+}$T-cells during chronic SIV infection of rhesus macaques. Front Immunol. (2019) 10:3005. doi: 10.3389/fimmu.2019.03005

73. Li L, Wan S, Tao K, Wang G, Zhao E. KLRG1 restricts memory $\mathrm{T}$ cell antitumor immunity. Oncotarget. (2016) 7:61670-8. doi: 10.18632/oncotarget.11430

74. Lines JL, Sempere LF, Broughton T, Wang L, Noelle R. VISTA is a novel broad-spectrum negative checkpoint regulator for cancer immunotherapy. Cancer Immunol Res. (2014) 2:510-7. doi: 10.1158/2326-6066.CIR-14-0072

75. Lines JL, Pantazi E, Mak J, Sempere LF, Wang L, O’Connell S, et al. VISTA is an immune checkpoint molecule for human T cells. Cancer Res. (2014) 74:1924-32. doi: 10.1158/0008-5472.CAN-13-1504

76. Le Mercier I, Chen W, Lines JL, Day M, Li J, Sergent P, et al. VISTA regulates the development of protective antitumor immunity. Cancer Res. (2014) 74:1933-44. doi: 10.1158/0008-5472.CAN-13-1506

77. Canale FP, Ramello MC, Nunez N, Araujo Furlan CL, Bossio SN, Gorosito Serran M, et al. CD39 expression defines cell exhaustion in tumor-infiltrating $\mathrm{CD}^{+} \mathrm{T}$ cells. Cancer Res. (2018) 78:115-28. doi: 10.1158/0008-5472.CAN-16-2684

78. Simoni Y, Becht E, Fehlings M, Loh CY, Koo SL, Teng KWW, et al. Bystander $\mathrm{CD}^{+} \mathrm{T}$ cells are abundant and phenotypically distinct in human tumour infiltrates. Nature. (2018) 557:575-9. doi: 10.1038/s41586-018-0130-2

79. Zheng Z, Cai Y, Chen H, Chen Z, Zhu D, Zhong Q, et al. CXCL13/CXCR5 axis predicts poor prognosis and promotes progression through PI3K/AKT/mTOR pathway in clear cell renal cell carcinoma. Front Oncol. (2018) 8:682. doi: 10.3389/fonc.2018.00682

80. Zheng C, Zheng L, Yoo JK, Guo H, Zhang Y, Guo X, et al. Landscape of infiltrating $\mathrm{T}$ cells in liver cancer revealed by single-cell sequencing. Cell. (2017) 169:1342-56.e16. doi: 10.1016/j.cell.2017.05.035

81. Stanczak MA, Siddiqui SS, Trefny MP, Thommen DS, Boligan KF, von Gunten S, et al. Self-associated molecular patterns mediate cancer immune evasion by engaging siglecs on T cells. J Clin Invest. (2018) 128:4912-23. doi: 10.1172/JCI120612

82. Alfei F, Kanev K, Hofmann M, Wu M, Ghoneim HE, Roelli P, et al. TOX reinforces the phenotype and longevity of exhausted $\mathrm{T}$ cells in chronic viral infection. Nature. (2019) 571:265-9. doi: 10.1038/s41586-019-1326-9

83. Khan O, Giles JR, McDonald S, Manne S, Ngiow SF, Patel KP, et al. TOX transcriptionally and epigenetically programs $\mathrm{CD}^{+} \mathrm{T}$ cell exhaustion. Nature. (2019) 571:211-8. doi: 10.1038/s41586-019-1325-x

84. LaFleur MW, Nguyen TH, Coxe MA, Miller BC, Yates KB, Gillis $\mathrm{JE}$, et al. PTPN2 regulates the generation of exhausted $\mathrm{CD}^{+} \mathrm{T}$ cell subpopulations and restrains tumor immunity. Nat Immunol. (2019) 20:1335-47. doi: 10.1038/s41590-019-0480-4

85. Chen Z, Ji Z, Ngiow SF, Manne S, Cai Z, Huang AC, et al. TCF-1-centered transcriptional network drives an effector versus exhausted CD8 T cell-fate decision. Immunity. (2019) 51:840-55.e5. doi: 10.1016/j.immuni.2019.09.013

86. Kujawski M, Zhang C, Herrmann A, Reckamp K, Scuto A, Jensen M, et al. Targeting STAT3 in adoptively transferred $\mathrm{T}$ cells promotes their in vivo expansion and antitumor effects. Cancer Res. (2010) 70:9599-610. doi: 10.1158/0008-5472.CAN-10-1293
87. Ciucci T, Vacchio MS, Bosselut R. A STAT3-dependent transcriptional circuitry inhibits cytotoxic gene expression in T cells. Proc Natl Acad Sci USA. (2017) 114:13236-41. doi: 10.1073/pnas.1711160114

88. Shin H, Blackburn SD, Intlekofer AM, Kao C, Angelosanto JM, Reiner $\mathrm{SL}$, et al. A role for the transcriptional repressor Blimp-1 in $\mathrm{CD}^{+}{ }^{+} \mathrm{T}$ cell exhaustion during chronic viral infection. Immunity. (2009) 31:309-20. doi: 10.1016/j.immuni.2009.06.019

89. Kallies A, Xin A, Belz GT, Nutt SL. Blimp-1 transcription factor is required for the differentiation of effector $\mathrm{CD} 8^{+} \mathrm{T}$ cells and memory responses. Immunity. (2009) 31:283-95. doi: 10.1016/j.immuni.2009.06.021

90. Nutt SL, Fairfax KA, Kallies A. BLIMP1 guides the fate of effector B and T cells. Nat Rev Immunol. (2007) 7:923-7. doi: 10.1038/nri2204

91. Thaventhiran JE, Fearon DT. Control of HIV infection: escape from the shadow of Blimp-1. Eur J Immunol. (2013) 43:323-6. doi: 10.1002/eji.201243263

92. Zhu L, Kong Y, Zhang J, Claxton DF, Ehmann WC, Rybka WB, et al. Blimp-1 impairs $\mathrm{T}$ cell function via upregulation of TIGIT and PD-1 in patients with acute myeloid leukemia. J Hematol Oncol. (2017) 10:124. doi: 10.1186/s13045-017-0486-z

93. Mann TH, Kaech SM. Tick-TOX, it's time for $\mathrm{T}$ cell exhaustion. Nat Immunol. (2019) 20:1092-4. doi: 10.1038/s41590-019-0478-y

94. Mathieu M, Cotta-Grand N, Daudelin JF, Thebault P, Labrecque N. Notch signaling regulates $\mathrm{PD}-1$ expression during $\mathrm{CD} 8^{+} \mathrm{T}$-cell activation. Immunol Cell Biol. (2013) 91:82-8. doi: 10.1038/icb.2012.53

95. Mognol GP, Spreafico R, Wong V, Scott-Browne JP, Togher S, Hoffmann $A$, et al. Exhaustion-associated regulatory regions in $\mathrm{CD}^{+}$tumorinfiltrating T cells. Proc Natl Acad Sci USA. (2017) 114:E2776-E85. doi: 10.1073/pnas.1620498114

96. Oestreich KJ, Yoon H, Ahmed R, Boss JM. NFATc1 regulates PD1 expression upon $\mathrm{T}$ cell activation. J Immunol. (2008) 181:4832-9. doi: 10.4049/jimmunol.181.7.4832

97. Kurachi M, Barnitz RA, Yosef N, Odorizzi PM, DiIorio MA, Lemieux ME, et al. The transcription factor BATF operates as an essential differentiation checkpoint in early effector CD8+ T cells. Nat Immunol. (2014) 15:373-83. doi: 10.1038/ni.2834

98. Murphy TL, Tussiwand R, Murphy KM. Specificity through cooperation: BATF-IRF interactions control immune-regulatory networks. Nat Rev Immunol. (2013) 13:499-509. doi: 10.1038/nri3470

99. Quigley M, Pereyra F, Nilsson B, Porichis F, Fonseca C, Eichbaum Q, et al. Transcriptional analysis of HIV-specific CD8+ T cells shows that PD-1 inhibits T cell function by upregulating BATF. Nat Med. (2010) 16:1147-51. doi: $10.1038 / \mathrm{nm} .2232$

100. Man K, Gabriel SS, Liao Y, Gloury R, Preston S, Henstridge DC, et al. Transcription factor IRF4 promotes $\mathrm{CD} 8^{+} \mathrm{T}$ cell exhaustion and limits the development of memory-like $\mathrm{T}$ cells during chronic infection. Immunity. (2017) 47:1129-41.e5. doi: 10.1016/j.immuni.2017.11.021

101. Doedens AL, Phan AT, Stradner MH, Fujimoto JK, Nguyen JV, Yang E, et al. Hypoxia-inducible factors enhance the effector responses of $\mathrm{CD}^{+}{ }^{+} \mathrm{T}$ cells to persistent antigen. Nat Immunol. (2013) 14:1173-82. doi: 10.1038/ni.2714

102. Staron MM, Gray SM, Marshall HD, Parish IA, Chen JH, Perry CJ, et al. The transcription factor FoxO1 sustains expression of the inhibitory receptor PD1 and survival of antiviral $\mathrm{CD}^{+} \mathrm{T}$ cells during chronic infection. Immunity. (2014) 41:802-14. doi: 10.1016/j.immuni.2014.10.013

103. Stephen TL, Rutkowski MR, Allegrezza MJ, Perales-Puchalt A, Tesone AJ, Svoronos N, et al. Transforming growth factor beta-mediated suppression of antitumor T cells requires FoxP1 transcription factor expression. Immunity. (2014) 41:427-39. doi: 10.1016/j.immuni.2014.08.012

104. Giordano M, Henin C, Maurizio J, Imbratta C, Bourdely P, Buferne M, et al. Molecular profiling of CD8 T cells in autochthonous melanoma identifies Maf as driver of exhaustion. EMBO J. (2015) 34:2042-58. doi: $10.15252 /$ embj.201490786

105. Singer M, Wang C, Cong L, Marjanovic ND, Kowalczyk MS, Zhang $\mathrm{H}$, et al. A distinct gene module for dysfunction uncoupled from activation in tumor-infiltrating $\mathrm{T}$ cells. Cell. (2016) 166:1500-11.e9. doi: 10.1016/j.cell.2016.08.052

106. Youngblood B, Oestreich KJ, Ha SJ, Duraiswamy J, Akondy RS, West EE, et al. Chronic virus infection enforces demethylation of the locus that 
encodes PD-1 in antigen-specific CD8 ${ }^{+}$T cells. Immunity. (2011) 35:400-12. doi: 10.1016/j.immuni.2011.06.015

107. Youngblood B, Noto A, Porichis F, Akondy RS, Ndhlovu ZM, Austin JW, et al. Cutting edge: prolonged exposure to HIV reinforces a poised epigenetic program for PD-1 expression in virus-specific CD8 T cells. J Immunol. (2013) 191:540-4. doi: 10.4049/jimmunol.1203161

108. Yang R, Masters AR, Fortner KA, Champagne DP, Yanguas-Casas N, Silberger DJ, et al. IL-6 promotes the differentiation of a subset of naive CD8+ T cells into IL-21-producing B helper CD8+ T cells. J Exp Med. (2016) 213:2281-91. doi: 10.1084/jem.20160417

109. Sen DR, Kaminski J, Barnitz RA, Kurachi M, Gerdemann U, Yates KB, et al. The epigenetic landscape of T cell exhaustion. Science. (2016) 354:1165-9. doi: 10.1126/science.aae0491

110. Zhu T, Hu Z, Wang Z, Ding H, Li R, Sun J, et al. Epigenetically silenced PD-L1 confers drug resistance to anti-PD1 therapy in gastric cardia adenocarcinoma. Int Immunopharmacol. (2020) 82:106245. doi: 10.1016/j.intimp.2020.106245

111. Pauken KE, Sammons MA, Odorizzi PM, Manne S, Godec J, Khan O, et al. Epigenetic stability of exhausted T cells limits durability of reinvigoration by PD-1 blockade. Science. (2016) 354:1160-5. doi: 10.1126/science.aaf2807

112. Philip M, Fairchild L, Sun L, Horste EL, Camara S, Shakiba M, et al. Chromatin states define tumour-specific $\mathrm{T}$ cell dysfunction and reprogramming. Nature. (2017) 545:452-6. doi: 10.1038/nature22367

113. Laino AS, Betts BC, Veerapathran A, Dolgalev I, Sarnaik A, Quayle $\mathrm{SN}$, et al. HDAC6 selective inhibition of melanoma patient T-cells augments anti-tumor characteristics. J Immunother Cancer. (2019) 7:33. doi: 10.1186/s40425-019-0517-0

114. Ghoneim HE, Fan Y, Moustaki A, Abdelsamed HA, Dash P, Dogra P, et al. De novo epigenetic programs inhibit PD-1 blockade-mediated T cell rejuvenation. Cell. (2017) 170:142-57.e19. doi: 10.1016/j.cell.2017.06.007

115. Bengsch B, Ohtani T, Herati RS, Bovenschen N, Chang KM, Wherry EJ. Deep immune profiling by mass cytometry links human T and NK cell differentiation and cytotoxic molecule expression patterns. J Immunol Methods. (2018) 453:3-10. doi: 10.1016/j.jim.2017.03.009

116. Dunn GP, Koebel CM, Schreiber RD. Interferons, immunity and cancer immunoediting. Nat Rev Immunol. (2006) 6:836-48. doi: 10.1038/nri1961

117. Schmiedel D, Mandelboim O. NKG2D ligands-critical targets for cancer immune escape and therapy. Front Immunol. (2018) 9:2040. doi: 10.3389/fimmu.2018.02040

118. Kang TW, Yevsa T, Woller N, Hoenicke L, Wuestefeld T, Dauch D, et al. Senescence surveillance of pre-malignant hepatocytes limits liver cancer development. Nature. (2011) 479:547-51. doi: 10.1038/nature10599

119. Willingham SB, Volkmer JP, Gentles AJ, Sahoo D, Dalerba P, Mitra SS, et al. The CD47-signal regulatory protein alpha (SIRPa) interaction is a therapeutic target for human solid tumors. Proc Natl Acad Sci USA. (2012) 109:6662-7. doi: 10.1073/pnas.1121623109

120. Biroccio A, Cherfils-Vicini J, Augereau A, Pinte S, Bauwens S, Ye J, et al. TRF2 inhibits a cell-extrinsic pathway through which natural killer cells eliminate cancer cells. Nat Cell Biol. (2013) 15:818-28. doi: 10.1038/ncb2774

121. Gajewski TF, Schreiber H, Fu YX. Innate and adaptive immune cells in the tumor microenvironment. Nat Immunol. (2013) 14:1014-22. doi: $10.1038 /$ ni.2703

122. Angelova M, Mlecnik B, Vasaturo A, Bindea G, Fredriksen T, Lafontaine L, et al. Evolution of metastases in space and time under immune selection. Cell. (2018) 175:751-65.e16. doi: 10.1016/j.cell.2018.09.018

123. Marvel D, Gabrilovich DI. Myeloid-derived suppressor cells in the tumor microenvironment: expect the unexpected. J Clin Invest. (2015) 125:3356-64. doi: $10.1172 / J C I 80005$

124. Quail DF, Joyce JA. Microenvironmental regulation of tumor progression and metastasis. Nat Med. (2013) 19:1423-37. doi: 10.1038/nm.3394

125. Chang CH, Qiu J, O'Sullivan D, Buck MD, Noguchi T, Curtis JD, et al. Metabolic competition in the tumor microenvironment is a driver of cancer progression. Cell. (2015) 162:1229-41. doi: 10.1016/j.cell.2015. 08.016

126. Ho PC, Bihuniak JD, Macintyre AN, Staron M, Liu X, Amezquita $\mathrm{R}$, et al. Phosphoenolpyruvate is a metabolic checkpoint of antitumor T cell responses. Cell. (2015) 162:1217-28. doi: 10.1016/j.cell.2015. 08.012
127. Kedia-Mehta N, Finlay DK. Competition for nutrients and its role in controlling immune responses. Nat Commun. (2019) 10:2123. doi: 10.1038/s41467-019-10015-4

128. Blackburn SD, Shin H, Freeman GJ, Wherry EJ. Selective expansion of a subset of exhausted CD8 T cells by alphaPD-L1 blockade. Proc Natl Acad Sci USA. (2008) 105:15016-21. doi: 10.1073/pnas.0801497105

129. Im SJ, Hashimoto M, Gerner MY, Lee J, Kissick HT, Burger MC, et al. Defining CD8+ $\mathrm{T}$ cells that provide the proliferative burst after PD-1 therapy. Nature. (2016) 537:417-21. doi: 10.1038/nature19330

130. Paley MA, Kroy DC, Odorizzi PM, Johnnidis JB, Dolfi DV, Barnett $\mathrm{BE}$, et al. Progenitor and terminal subsets of $\mathrm{CD} 8+\mathrm{T}$ cells cooperate to contain chronic viral infection. Science. (2012) 338:1220-5. doi: 10.1126/science. 1229620

131. He R, Hou S, Liu C, Zhang A, Bai Q, Han M, et al. Follicular CXCR5expressing $\mathrm{CD}^{+} \mathrm{T}$ cells curtail chronic viral infection. Nature. (2016) 537:412-28. doi: 10.1038/nature19317

132. Thommen DS, Koelzer VH, Herzig P, Roller A, Trefny M, Dimeloe S, et al. A transcriptionally and functionally distinct $\mathrm{PD}-1^{+} \mathrm{CD} 8^{+} \mathrm{T}$ cell pool with predictive potential in non-small-cell lung cancer treated with PD-1 blockade. Nat Med. (2018) 24:994-1004. doi: 10.1038/s41591-018-0057-z

133. Utzschneider DT, Alfei F, Roelli P, Barras D, Chennupati V, Darbre S, et al. High antigen levels induce an exhausted phenotype in a chronic infection without impairing T cell expansion and survival. J Exp Med. (2016) 213:1819-34. doi: 10.1084/jem.20150598

134. Wu T, Ji Y, Moseman EA, Xu HC, Manglani M, Kirby M, et al. The TCF1-Bcl6 axis counteracts type I interferon to repress exhaustion and maintain $\mathrm{T}$ cell stemness. Sci Immunol. (2016) 1:eaai8593. doi: 10.1126/sciimmunol.aai8593

135. Siddiqui I, Schaeuble K, Chennupati V, Fuertes Marraco SA, CalderonCopete S, Pais Ferreira D, et al. Intratumoral Tcf1 ${ }^{+} \mathrm{PD}-1^{+} \mathrm{CD} 8^{+} \mathrm{T}$ Cells with stem-like properties promote tumor control in response to vaccination and checkpoint blockade immunotherapy. Immunity. (2019) 50:195-211.e10. doi: 10.1016/j.immuni.2018.12.021

136. Le KS, Ame-Thomas P, Tarte K, Gondois-Rey F, Granjeaud S, Orlanducci F, et al. CXCR5 and ICOS expression identifies a CD8 T-cell subset with TFH features in hodgkin lymphomas. Blood Adv. (2018) 2:1889-900. doi: 10.1182/bloodadvances.2018017244

137. Xing J, Zhang C, Yang X, Wang S, Wang Z, Li X, et al. CXCR5 ${ }^{+} \mathrm{CD} 8^{+} \mathrm{T}$ cells infiltrate the colorectal tumors and nearby lymph nodes, and are associated with enhanced IgG response in B cells. Exp Cell Res. (2017) 356:57-63. doi: 10.1016/j.yexcr.2017.04.014

138. Ferrando-Martinez S, Moysi E, Pegu A, Andrews S, Nganou Makamdop K, Ambrozak D, et al. Accumulation of follicular CD8+ T cells in pathogenic SIV infection. J Clin Invest. (2018) 128:2089-103. doi: 10.1172/JCI96207

139. Bai M, Zheng Y, Liu H, Su B, Zhan Y, He H. CXCR5 ${ }^{+} \mathrm{CD} 8^{+}$T cells potently infiltrate pancreatic tumors and present high functionality. Exp Cell Res. (2017) 361:39-45. doi: 10.1016/j.yexcr.2017.09.039

140. Brummelman J, Mazza EMC, Alvisi G, Colombo FS, Grilli A, Mikulak J, et al. High-dimensional single cell analysis identifies stem-like cytotoxic $\mathrm{CD}^{+} \mathrm{T}$ cells infiltrating human tumors. J Exp Med. (2018) 215:2520-35. doi: $10.1084 /$ jem. 20180684

141. Jifu E, Yan F, Kang Z, Zhu L, Xing J, Yu E. $\mathrm{CD}^{+} \mathrm{CXCR}^{+} \mathrm{T}$ cells in tumor-draining lymph nodes are highly activated and predict better prognosis in colorectal cancer. Hum Immunol. (2018) 79:446-52. doi: 10.1016/j.humimm.2018.03.003

142. Valentine KM, Davini D, Lawrence TJ, Mullins GN, Manansala M, Al-Kuhlani $\mathrm{M}$, et al. CD8 follicular $\mathrm{T}$ cells promote B cell antibody class switch in autoimmune disease. J Immunol. (2018) 201:31-40. doi: 10.4049/jimmunol.1701079

143. Quigley MF, Gonzalez VD, Granath A, Andersson J, Sandberg JK. CXCR5+ CCR7- CD8 T cells are early effector memory cells that infiltrate tonsil B cell follicles. Eur J Immunol. (2007) 37:3352-62. doi: 10.1002/eji.200636746

144. Chu F, Li HS, Liu X, Cao J, Ma W, Ma Y, et al. CXCR5 $5^{+} \mathrm{CD}^{+} \mathrm{T}$ cells are a distinct functional subset with an antitumor activity. Leukemia. (2019) 33:2640-53. doi: 10.1038/s41375-019-0464-2

145. Im SJ, Konieczny BT, Hudson WH, Masopust D, Ahmed R. PD$1+$ stemlike CD8 T cells are resident in lymphoid tissues during persistent LCMV infection. Proc Natl Acad Sci USA. (2020) 117:4292-9. doi: $10.1073 /$ pnas. 1917298117 
146. Mylvaganam GH, Rios D, Abdelaal HM, Iyer S, Tharp G, Mavigner $M$, et al. Dynamics of SIV-specific CXCR5+ CD8 T cells during chronic SIV infection. Proc Natl Acad Sci USA. (2017) 114:1976-81. doi: $10.1073 /$ pnas. 1621418114

147. Kim HJ, Verbinnen B, Tang X, Lu L, Cantor H. Inhibition of follicular Thelper cells by $\mathrm{CD} 8^{+}$regulatory $\mathrm{T}$ cells is essential for self tolerance. Nature. (2010) 467:328-32. doi: 10.1038/nature09370

148. Leong YA, Chen Y, Ong HS, Wu D, Man K, Deleage C, et al. CXCR5 ${ }^{+}$ follicular cytotoxic $\mathrm{T}$ cells control viral infection in B cell follicles. Nat Immunol. (2016) 17:1187-96. doi: 10.1038/ni.3543

149. Jin Y, Lang C, Tang J, Geng J, Song HK, Sun Z, et al. CXCR5 ${ }^{+} \mathrm{CD}^{+}$ $\mathrm{T}$ cells could induce the death of tumor cells in HBV-related hepatocellular carcinoma. Int Immunopharmacol. (2017) 53:42-8. doi: 10.1016/j.intimp.2017.10.009

150. Scott AC, Dundar F, Zumbo P, Chandran SS, Klebanoff CA, Shakiba M, et al. TOX is a critical regulator of tumour-specific T cell differentiation. Nature. (2019) 571:270-4. doi: 10.1038/s41586-019-1324-y

151. Seo H, Chen J, Gonzalez-Avalos E, Samaniego-Castruita D, Das A, Wang $\mathrm{YH}$, et al. TOX and TOX2 transcription factors cooperate with NR4A transcription factors to impose CD8 ${ }^{+} \mathrm{T}$ cell exhaustion. Proc Natl Acad Sci USA. (2019) 116:12410-5. doi: 10.1073/pnas.1905675116

152. Yao C, Sun HW, Lacey NE, Ji Y, Moseman EA, Shih HY, et al. Single-cell RNA-seq reveals TOX as a key regulator of $\mathrm{CD}^{+} \mathrm{T}$ cell persistence in chronic infection. Nat Immunol. (2019) 20:890-901. doi: 10.1038/s41590-019-0403-4

153. Appay V, Dunbar PR, Callan M, Klenerman P, Gillespie GM, Papagno $\mathrm{L}$, et al. Memory CD8+ $\mathrm{T}$ cells vary in differentiation phenotype in different persistent virus infections. Nat Med. (2002) 8:379-85. doi: $10.1038 / \mathrm{nm} 0402-379$

154. Mueller YM, De Rosa SC, Hutton JA, Witek J, Roederer M, Altman JD, et al. Increased CD95/Fas-induced apoptosis of HIV-specific CD8 ${ }^{+} \mathrm{T}$ cells. Immunity. (2001) 15:871-82. doi: 10.1016/S1074-7613(01)00246-1

155. Betts MR, Nason MC, West SM, De Rosa SC, Migueles SA, Abraham J, et al. HIV nonprogressors preferentially maintain highly functional HIV-specific CD8+ T cells. Blood. (2006) 107:4781-9. doi: 10.1182/blood-2005-12-4818

156. Crawford A, Angelosanto JM, Nadwodny KL, Blackburn SD, Wherry EJ. A role for the chemokine RANTES in regulating CD8 T cell responses during chronic viral infection. PLoS Pathog. (2011) 7:e1002098. doi: 10.1371/journal.ppat.1002098

157. Greenwald RJ, Freeman GJ, Sharpe AH. The B7 family revisited. Аnпu Rev Immunol. (2005) 23:515-48. doi: 10.1146/annurev.immunol.23.021704.115611

158. Bhadra R, Gigley JP, Weiss LM, Khan IA. Control of Toxoplasma reactivation by rescue of dysfunctional CD8+ T-cell response via PD-1-PDL-1 blockade. Proc Natl Acad Sci USA. (2011) 108:9196-201. doi: 10.1073/pnas.10152 98108

159. Kao C, Oestreich KJ, Paley MA, Crawford A, Angelosanto JM, Ali MA, et al. Transcription factor T-bet represses expression of the inhibitory receptor PD-1 and sustains virus-specific CD8+ T cell responses during chronic infection. Nat Immunol. (2011) 12:663-71. doi: 10.1038/ni.2046

160. Lu P, Youngblood BA, Austin JW, Mohammed AU, Butler R, Ahmed $\mathrm{R}$, et al. Blimp-1 represses CD8 T cell expression of PD-1 using a feedforward transcriptional circuit during acute viral infection. J Exp Med. (2014) 211:515-27. doi: $10.1084 / \mathrm{jem} .20130208$

161. Lee MS, Park CH, Jeong YH, Kim YJ, Ha SJ. Negative regulation of type I IFN expression by OASL1 permits chronic viral infection and $\mathrm{CD}^{+}$T-cell exhaustion. PLoS Pathog. (2013) 9:e1003478. doi: 10.1371/journal.ppat.1003478

162. Petrovas C, Chaon B, Ambrozak DR, Price DA, Melenhorst JJ, Hill BJ, et al. Differential association of programmed death-1 and CD57 with ex vivo survival of CD8+ T cells in HIV infection. J Immunol. (2009) 183:1120-32. doi: 10.4049/jimmunol.0900182

163. Petrovas C, Yamamoto T, Price DA, Rao SS, Klatt NR, Brenchley JM, et al. High production rates sustain in vivo levels of PD-1high simian immunodeficiency virus-specific CD8 T cells in the face of rapid clearance. J Virol. (2013) 87:9836-44. doi: 10.1128/JVI.01001-13

164. Sheppard KA, Fitz LJ, Lee JM, Benander C, George JA, Wooters J, et al. PD1 inhibits T-cell receptor induced phosphorylation of the ZAP70/CD3zeta signalosome and downstream signaling to PKCtheta. FEBS Lett. (2004) 574:37-41. doi: 10.1016/j.febslet.2004.07.083

165. Yokosuka T, Takamatsu M, Kobayashi-Imanishi W, Hashimoto-Tane A, Azuma M, Saito T. Programmed cell death 1 forms negative costimulatory microclusters that directly inhibit $\mathrm{T}$ cell receptor signaling by recruiting phosphatase SHP2. J Exp Med. (2012) 209:1201-17. doi: 10.1084/jem.20112741

166. Hui E, Cheung J, Zhu J, Su X, Taylor MJ, Wallweber HA, et al. T cell costimulatory receptor $\mathrm{CD} 28$ is a primary target for PD-1-mediated inhibition. Science. (2017) 355:1428-33. doi: 10.1126/science.aaf1292

167. Kamphorst AO, Wieland A, Nasti T, Yang S, Zhang R, Barber DL, et al. Rescue of exhausted CD8 T cells by PD-1-targeted therapies is CD28dependent. Science. (2017) 355:1423-7. doi: 10.1126/science.aaf0683

168. Parry RV, Chemnitz JM, Frauwirth KA, Lanfranco AR, Braunstein I, Kobayashi SV, et al. CTLA-4 and PD-1 receptors inhibit T-cell activation by distinct mechanisms. Mol Cell Biol. (2005) 25:9543-53. doi: 10.1128/MCB.25.21.9543-9553.2005

169. Schurich A, Pallett LJ, Jajbhay D, Wijngaarden J, Otano I, Gill US, et al. Distinct metabolic requirements of exhausted and functional virusspecific CD8 T cells in the same host. Cell Rep. (2016) 16:1243-52. doi: 10.1016/j.celrep.2016.06.078

170. Jiao YM, Yang HG, Huang HH, Tu B, Xing SJ, Mao L, et al. Dichotomous roles of programmed cell death 1 on HIV-specific CXCR5 ${ }^{+}$and CXCR5 ${ }^{-}$ $\mathrm{CD}^{+}{ }^{+} \mathrm{T}$ cells during chronic HIV infection. Front Immunol. (2017) 8:1786. doi: 10.3389/fimmu.2017.01786

171. Kaufmann DE, Kavanagh DG, Pereyra F, Zaunders JJ, Mackey EW, Miura $\mathrm{T}$, et al. Upregulation of CTLA- 4 by HIV-specific CD4+ T cells correlates with disease progression and defines a reversible immune dysfunction. Nat Immunol. (2007) 8:1246-54. doi: 10.1038/ni1515

172. Kaufmann DE, Walker BD. PD-1 and CTLA-4 inhibitory cosignaling pathways in HIV infection and the potential for therapeutic intervention. J Immunol. (2009) 182:5891-7. doi: 10.4049/jimmunol.0803771

173. Cornberg M, Kenney LL, Chen AT, Waggoner SN, Kim SK, Dienes $\mathrm{HP}$, et al. Clonal exhaustion as a mechanism to protect against severe immunopathology and death from an overwhelming CD8 $\mathrm{T}$ cell response. Front Immunol. (2013) 4:475. doi: 10.3389/fimmu.2013.00475

174. Salek-Ardakani S, Schoenberger SP. T cell exhaustion: a means or an end? Nat Immunol. (2013) 14:531-3. doi: 10.1038/ni.2619

175. Utzschneider DT, Legat A, Fuertes Marraco SA, Carrie L, Luescher I, Speiser DE, et al. T cells maintain an exhausted phenotype after antigen withdrawal and population reexpansion. Nat Immunol. (2013) 14:603-10. doi: $10.1038 /$ ni.2606

176. Vigano S, Banga R, Bellanger F, Pellaton C, Farina A, Comte $\mathrm{D}$, et al. CD160-associated CD8 T-cell functional impairment is independent of PD-1 expression. PLoS Pathog. (2014) 10:e1004380. doi: 10.1371/journal.ppat. 1004380

177. Velu V, Titanji K, Zhu B, Husain S, Pladevega A, Lai L, et al. Enhancing SIV-specific immunity in vivo by PD-1 blockade. Nature. (2009) 458:206-10. doi: $10.1038 /$ nature 07662

178. Dyavar Shetty R, Velu V, Titanji K, Bosinger SE, Freeman GJ, Silvestri G, et al. PD-1 blockade during chronic SIV infection reduces hyperimmune activation and microbial translocation in rhesus macaques. J Clin Invest. (2012) 122:1712-6. doi: 10.1172/JCI60612

179. Finnefrock AC, Tang A, Li F, Freed DC, Feng M, Cox KS, et al. PD-1 blockade in rhesus macaques: impact on chronic infection and prophylactic vaccination. J Immunol. (2009) 182:980-7. doi: 10.4049/jimmunol.182.2.980

180. Titanji K, Velu V, Chennareddi L, Vijay-Kumar M, Gewirtz AT, Freeman GJ, et al. Acute depletion of activated memory B cells involves the PD-1 pathway in rapidly progressing SIV-infected macaques. J Clin Invest. (2010) 120:3878-90. doi: 10.1172/JCI43271

181. Amancha PK, Hong JJ, Rogers K, Ansari AA, Villinger F. In vivo blockade of the programmed cell death-1 pathway using soluble recombinant PD-1-Fc enhances $\mathrm{CD} 4+$ and $\mathrm{CD} 8+\mathrm{T}$ cell responses but has limited clinical benefit. J Immunol. (2013) 191:6060-70. doi: 10.4049/jimmunol.1302044

182. Gay CL, Bosch RJ, Ritz J, Hataye JM, Aga E, Tressler RL, et al. Clinical trial of the anti-PD-L1 antibody BMS-936559 in HIV-1 infected participants on suppressive antiretroviral therapy. J Infect Dis. (2017) 215:1725-33. doi: 10.1093/infdis/jix191 
183. Mylvaganam GH, Chea LS, Tharp GK, Hicks S, Velu V, Iyer SS, et al. Combination anti-PD-1 and antiretroviral therapy provides therapeutic benefit against SIV. JCI Insight. (2018) 3:e122940. doi: $10.1172 /$ jci.insight. 122940

184. Bekerman E, Hesselgesser J, Carr B, Nagel M, Hung M, Wang A, et al. PD-1 blockade and TLR7 activation lack therapeutic benefit in chronic simian immunodeficiency virus-infected macaques on antiretroviral therapy. Antimicrob Agents Chemother. (2019) 63: e01163-19. doi: 10.1128/AAC.01163-19

185. Davar D, Wilson M, Pruckner C, Kirkwood JM. PD-1 blockade in advanced melanoma in patients with hepatitis C and/or HIV. Case Rep Oncol Med. (2015) 2015:737389. doi: 10.1155/2015/737389

186. Evans VA, van der Sluis RM, Solomon A, Dantanarayana A, McNeil C, Garsia R, et al. Programmed cell death-1 contributes to the establishment and maintenance of HIV-1 latency. AIDS. (2018) 32:1491-7. doi: 10.1097/QAD.0000000000001849

187. Le Garff G, Samri A, Lambert-Niclot S, Even S, Lavole A, Cadranel J, et al. Transient HIV-specific $\mathrm{T}$ cells increase and inflammation in an HIV-infected patient treated with nivolumab. AIDS. (2017) 31:1048-51. doi: 10.1097/QAD.0000000000001429

188. Wightman F, Solomon A, Kumar SS, Urriola N, Gallagher K, Hiener B, et al. Effect of ipilimumab on the HIV reservoir in an HIVinfected individual with metastatic melanoma. AIDS. (2015) 29:504-6. doi: 10.1097/QAD.0000000000000562

189. Freeman GJ, Wherry EJ, Ahmed R, Sharpe AH. Reinvigorating exhausted HIV-specific T cells via PD-1-PD-1 ligand blockade. J Exp Med. (2006) 203:2223-7. doi: 10.1084/jem.20061800

190. Gill AL, Green SA, Abdullah S, Le Saout C, Pittaluga S, Chen H, et al. Programed death-1/programed death-ligand 1 expression in lymph nodes of HIV infected patients: results of a pilot safety study in rhesus macaques using anti-programed death-ligand 1 (Avelumab). AIDS. (2016) 30:2487-93. doi: 10.1097/QAD.0000000000001217

191. Doering TA, Crawford A, Angelosanto JM, Paley MA, Ziegler CG, Wherry EJ. Network analysis reveals centrally connected genes and pathways involved in CD8+ T cell exhaustion versus memory. Immunity. (2012) 37:1130-44. doi: 10.1016/j.immuni.2012.08.021

192. Agnellini P, Wolint P, Rehr M, Cahenzli J, Karrer U, Oxenius A. Impaired NFAT nuclear translocation results in split exhaustion of virus-specific CD8 + T cell functions during chronic viral infection. Proc Natl Acad Sci USA. (2007) 104:4565-70. doi: 10.1073/pnas.0610335104

193. Martinez GJ, Pereira RM, Aijo T, Kim EY, Marangoni F, Pipkin ME, et al. The transcription factor NFAT promotes exhaustion of activated $\mathrm{CD} 8^{+} \mathrm{T}$ cells. Immunity. (2015) 42:265-78. doi: 10.1016/j.immuni.2015.01.006

194. Martins G, Calame K. Regulation and functions of Blimp-1 in $\mathrm{T}$ and B lymphocytes. Annu Rev Immunol. (2008) 26:133-69. doi: 10.1146/annurev.immunol.26.021607.090241

195. Sullivan JA, Kim EH, Plisch EH, Peng SL, Suresh M. FOXO3 regulates CD8 T cell memory by T cell-intrinsic mechanisms. PLoS Pathog. (2012) 8:e1002533. doi: 10.1371/journal.ppat.1002533

196. Sullivan JA, Kim EH, Plisch EH, Suresh M. FOXO3 regulates the CD8 T cell response to a chronic viral infection. J Virol. (2012) 86:9025-34. doi: 10.1128/JVI.00942-12

197. Tzelepis F, Joseph J, Haddad EK, Maclean S, Dudani R, Agenes F, et al. Intrinsic role of FoxO3a in the development of CD8+ T cell memory. $J$ Immunol. (2013) 190:1066-75. doi: 10.4049/jimmunol.1200639

198. van Grevenynghe J, Procopio FA, He Z, Chomont N, Riou C, Zhang Y, et al. Transcription factor FOXO3a controls the persistence of memory CD4 ${ }^{+} \mathrm{T}$ cells during HIV infection. Nat Med. (2008) 14:266-74. doi: 10.1038/nm1728

199. Cherkassky L, Morello A, Villena-Vargas J, Feng Y, Dimitrov DS, Jones $\mathrm{DR}$, et al. Human CAR $\mathrm{T}$ cells with cell-intrinsic PD-1 checkpoint blockade resist tumor-mediated inhibition. J Clin Invest. (2016) 126:3130-44. doi: 10.1172/JCI83092

200. Buggert M, Tauriainen J, Yamamoto T, Frederiksen J, Ivarsson MA, Michaelsson J, et al. T-bet and eomes are differentially linked to the exhausted phenotype of CD8 + T cells in HIV infection. PLoS Pathog. (2014) 10:e1004251. doi: 10.1371/journal.ppat.1004251
201. Odorizzi PM, Pauken KE, Paley MA, Sharpe A, Wherry EJ. Genetic absence of PD-1 promotes accumulation of terminally differentiated exhausted CD8+ T cells. J Exp Med. (2015) 212:1125-37. doi: 10.1084/jem.20142237

202. Boise LH, Thompson CB. Hierarchical control of lymphocyte survival. Science. (1996) 274:67-8. doi: 10.1126/science.274.5284.67

203. Seddiki N, Phetsouphanh C, Swaminathan S, Xu Y, Rao S, Li J, et al. The microRNA-9/B-lymphocyte-induced maturation protein-1/IL-2 axis is differentially regulated in progressive HIV infection. Eur J Immunol. (2013) 43:510-20. doi: 10.1002/eji.201242695

204. de Masson A, Kirilovsky A, Zoorob R, Avettand-Fenoel V, Morin V, Oudin A, et al. Blimp-1 overexpression is associated with low HIV-1 reservoir and transcription levels in central memory CD4+ T cells from elite controllers. AIDS. (2014) 28:1567-77. doi: 10.1097/QAD.0000000000000295

205. Shankar EM, Che KF, Messmer D, Lifson JD, Larsson M. Expression of a broad array of negative costimulatory molecules and Blimp-1 in T cells following priming by HIV-1 pulsed dendritic cells. Mol Med. (2011) 17:22940. doi: 10.2119/molmed.2010.00175

206. Buenrostro JD, Giresi PG, Zaba LC, Chang HY, Greenleaf WJ. Transposition of native chromatin for fast and sensitive epigenomic profiling of open chromatin, DNA-binding proteins and nucleosome position. Nat Methods. (2013) 10:1213-8. doi: 10.1038/nmeth.2688

207. Scharer CD, Bally AP, Gandham B, Boss JM. Cutting edge: chromatin accessibility programs CD8 T cell memory. J Immunol. (2017) 198:2238-43. doi: 10.4049/jimmunol.1602086

208. Scott-Browne JP, Lopez-Moyado IF, Trifari S, Wong V, Chavez L, Rao A, et al. Dynamic changes in chromatin accessibility occur in CD8 ${ }^{+}$ $\mathrm{T}$ cells responding to viral infection. Immunity. (2016) 45:1327-40. doi: 10.1016/j.immuni.2016.10.028

209. Zhang F, Zhou X, DiSpirito JR, Wang C, Wang Y, Shen H. Epigenetic manipulation restores functions of defective $\mathrm{CD}^{+} \mathrm{T}$ cells from chronic viral infection. Mol Ther. (2014) 22:1698-706. doi: 10.1038/mt.2014.91

210. Boni C, Fisicaro P, Valdatta C, Amadei B, Di Vincenzo P, Giuberti $\mathrm{T}$, et al. Characterization of hepatitis B virus (HBV)-specific T-cell dysfunction in chronic HBV infection. J Virol. (2007) 81:4215-25. doi: 10.1128/JVI.02844-06

211. Radziewicz H, Ibegbu CC, Fernandez ML, Workowski KA, Obideen K, Wehbi $\mathrm{M}$, et al. Liver-infiltrating lymphocytes in chronic human hepatitis $\mathrm{C}$ virus infection display an exhausted phenotype with high levels of PD-1 and low levels of CD127 expression. J Virol. (2007) 81:2545-53. doi: 10.1128/JVI.02021-06

212. Urbani S, Amadei B, Tola D, Massari M, Schivazappa S, Missale G, et al. PD-1 expression in acute hepatitis $\mathrm{C}$ virus (HCV) infection is associated with HCV-specific CD8 exhaustion. J Virol. (2006) 80:11398-403. doi: 10.1128/JVI.01177-06

213. Wherry EJ, Blattman JN, Murali-Krishna K, van der Most R, Ahmed R. Viral persistence alters CD8 T-cell immunodominance and tissue distribution and results in distinct stages of functional impairment. J Virol. (2003) 77:4911-27. doi: 10.1128/JVI.77.8.4911-4927.2003

214. Mueller SN, Ahmed R. High antigen levels are the cause of T cell exhaustion during chronic viral infection. Proc Natl Acad Sci USA. (2009) 106:8623-8. doi: 10.1073/pnas.0809818106

215. Fuller MJ, Khanolkar A, Tebo AE, Zajac AJ. Maintenance, loss, and resurgence of $\mathrm{T}$ cell responses during acute, protracted, and chronic viral infections. J Immunol. (2004) 172:4204-14. doi: 10.4049/jimmunol.172.7.4204

216. Fuller MJ, Zajac AJ. Ablation of CD8 and CD4 T cell responses by high viral loads. J Immunol. (2003) 170:477-86. doi: 10.4049/jimmunol.170.1.477

217. Gallimore A, Glithero A, Godkin A, Tissot AC, Pluckthun A, Elliott T, et al. Induction and exhaustion of lymphocytic choriomeningitis virusspecific cytotoxic $\mathrm{T}$ lymphocytes visualized using soluble tetrameric major histocompatibility complex class I-peptide complexes. J Exp Med. (1998) 187:1383-93. doi: 10.1084/jem.187.9.1383

218. Ou R, Zhou S, Huang L, Moskophidis D. Critical role for alpha/beta and gamma interferons in persistence of lymphocytic choriomeningitis virus by clonal exhaustion of cytotoxic T cells. J Virol. (2001) 75:8407-23. doi: 10.1128/JVI.75.18.8407-8423.2001 
219. Wei F, Zhong S, Ma Z, Kong H, Medvec A, Ahmed R, et al. Strength of PD1 signaling differentially affects T-cell effector functions. Proc Natl Acad Sci USA. (2013) 110:E2480-9. doi: 10.1073/pnas.1305394110

220. Savage PA, Leventhal DS, Malchow S. Shaping the repertoire of tumorinfiltrating effector and regulatory T cells. Immunol Rev. (2014) 259:245-58. doi: $10.1111 /$ imr.12166

221. Attanasio J, Wherry EJ. Costimulatory and coinhibitory receptor pathways in infectious disease. Immunity. (2016) 44:1052-68. doi: 10.1016/j.immuni.2016.04.022

222. Pellegrini M, Calzascia T, Elford AR, Shahinian A, Lin AE, Dissanayake D, et al. Adjuvant IL-7 antagonizes multiple cellular and molecular inhibitory networks to enhance immunotherapies. Nat Med. (2009) 15:52836. doi: 10.1038/nm.1953

223. Saeidi A, Zandi K, Cheok YY, Saeidi H, Wong WF, Lee CYQ, et al. Tcell exhaustion in chronic infections: reversing the state of exhaustion and reinvigorating optimal protective immune responses. Front Immunol. (2018) 9:2569. doi: 10.3389/fimmu.2018.02569

224. Yerinde C, Siegmund B, Glauben R, Weidinger C. Metabolic control of epigenetics and its role in $\mathrm{CD} 8^{+} \mathrm{T}$ cell differentiation and function. Front Immunol. (2019) 10:2718. doi: 10.3389/fimmu.2019.02718

225. Scharping NE, Menk AV, Moreci RS, Whetstone RD, Dadey RE, Watkins SC, et al. The tumor microenvironment represses $\mathrm{T}$ cell mitochondrial biogenesis to drive intratumoral $\mathrm{T}$ cell metabolic insufficiency and dysfunction. Immunity. (2016) 45:701-3. doi: 10.1016/j.immuni.2016.08.009

226. Black M, Barsoum IB, Truesdell P, Cotechini T, Macdonald-Goodfellow SK, Petroff M, et al. Activation of the PD-1/PD-L1 immune checkpoint confers tumor cell chemoresistance associated with increased metastasis. Oncotarget. (2016) 7:10557-67. doi: 10.18632/oncotarget.7235

227. Ghebeh H, Lehe C, Barhoush E, Al-Romaih K, Tulbah A, Al-Alwan M, et al. Doxorubicin downregulates cell surface B7-H1 expression and upregulates its nuclear expression in breast cancer cells: role of B7-H1 as an antiapoptotic molecule. Breast Cancer Res. (2010) 12:R48. doi: 10.1186/bc r2605

228. Liu WM, Fowler DW, Smith P, Dalgleish AG. Pre-treatment with chemotherapy can enhance the antigenicity and immunogenicity of tumours by promoting adaptive immune responses. Br J Cancer. (2010) 102:115-23. doi: $10.1038 /$ sj.bjc.6605465

229. Sharma MD, Huang L, Choi JH, Lee EJ, Wilson JM, Lemos H, et al. An inherently bifunctional subset of Foxp3 $+\mathrm{T}$ helper cells is controlled by the transcription factor eos. Immunity. (2013) 38:998-1012. doi: 10.1016/j.immuni.2013.01.013

230. Mellman I, Coukos G, Dranoff G. Cancer immunotherapy comes of age. Nature. (2011) 480:480-9. doi: 10.1038/nature10673

231. Thommen DS, Schreiner J, Muller P, Herzig P, Roller A, Belousov A, et al. Progression of lung cancer is associated with increased dysfunction of T cells defined by coexpression of multiple inhibitory receptors. Cancer Immunol Res. (2015) 3:1344-55. doi: 10.1158/2326-6066.CIR-15-0097

232. Tang J, Zha J, Guo X, Shi P, Xu B. CXCR $5^{+} \mathrm{CD} 8^{+} \mathrm{T}$ cells present elevated capacity in mediating cytotoxicity toward autologous tumor cells through interleukin 10 in diffuse large B-cell lymphoma. Int Immunopharmacol. (2017) 50:146-51. doi: 10.1016/j.intimp.2017.06.020

233. Mastelic-Gavillet B, Navarro Rodrigo B, Decombaz L, Wang H, Ercolano G, Ahmed R, et al. Adenosine mediates functional and metabolic suppression of peripheral and tumor-infiltrating $\mathrm{CD}^{+} \mathrm{T}$ cells. J Immunother Cancer. (2019) 7:257. doi: 10.1186/s40425-019-0719-5

234. Speiser DE, Ho PC, Verdeil G. Regulatory circuits of T cell function in cancer. Nat Rev Immunol. (2016) 16:599-611. doi: 10.1038/nri.2016.80

235. Choi YS, Eto D, Yang JA, Lao C, Crotty S. Cutting edge: STAT1 is required for IL-6-mediated Bcl6 induction for early follicular helper cell differentiation. J Immunol. (2013) 190:3049-53. doi: 10.4049/jimmunol.1203032

236. Yue C, Shen S, Deng J, Priceman SJ, Li W, Huang A, et al. STAT3 in $\mathrm{CD} 8+\mathrm{T}$ cells inhibits their tumor accumulation by downregulating CXCR3/CXCL10 axis. Cancer Immunol Res. (2015) 3:864-70. doi: 10.1158/2326-6066.CIR-15-0014

237. Zippelius A, Batard P, Rubio-Godoy V, Bioley G, Lienard D, Lejeune F, et al. Effector function of human tumor-specific CD8 T cells in melanoma lesions: a state of local functional tolerance. Cancer Res. (2004) 64:2865-73. doi: 10.1158/0008-5472.CAN-03-3066
238. Li H, van der Leun AM, Yofe I, Lubling Y, Gelbard-Solodkin D, van Akkooi ACJ, et al. Dysfunctional CD8 T cells form a proliferative, dynamically regulated compartment within human melanoma. Cell. (2019) 176:77589.e18. doi: 10.1016/j.cell.2018.11.043

239. Matsuzaki J, Gnjatic S, Mhawech-Fauceglia P, Beck A, Miller A, Tsuji T, et al. Tumor-infiltrating NY-ESO-1-specific CD8 + T cells are negatively regulated by LAG-3 and PD-1 in human ovarian cancer. Proc Natl Acad Sci USA. (2010) 107:7875-80. doi: 10.1073/pnas.1003345107

240. Speiser DE, Utzschneider DT, Oberle SG, Munz C, Romero P, Zehn D. T cell differentiation in chronic infection and cancer: functional adaptation or exhaustion? Nat Rev Immunol. (2014) 14:768-74. doi: 10.1038/nri3740

241. Gros A, Parkhurst MR, Tran E, Pasetto A, Robbins PF, Ilyas S, et al. Prospective identification of neoantigen-specific lymphocytes in the peripheral blood of melanoma patients. Nat Med. (2016) 22:433-8. doi: $10.1038 / \mathrm{nm} .4051$

242. Gros A, Robbins PF, Yao X, Li YF, Turcotte S, Tran E, et al. PD-1 identifies the patient-specific $\mathrm{CD}^{+}$tumor-reactive repertoire infiltrating human tumors. J Clin Invest. (2014) 124:2246-59. doi: 10.1172/JCI73639

243. Inozume $\mathrm{T}$, Hanada $\mathrm{K}$, Wang QJ, Ahmadzadeh $\mathrm{M}$, Wunderlich JR, Rosenberg SA, et al. Selection of CD8+PD-1+ lymphocytes in fresh human melanomas enriches for tumor-reactive $\mathrm{T}$ cells. J Immunother. (2010) 33:956-64. doi: 10.1097/CJI.0b013e3181fad2b0

244. Egelston CA, Avalos C, Tu TY, Simons DL, Jimenez G, Jung JY, et al. Human breast tumor-infiltrating $\mathrm{CD}^{+} \mathrm{T}$ cells retain polyfunctionality despite $\mathrm{PD}-1$ expression. Nat Commun. (2018) 9:4297. doi: 10.1038/s41467-018-06653-9

245. Wherry EJ, Barber DL, Kaech SM, Blattman JN, Ahmed R. Antigenindependent memory CD8 T cells do not develop during chronic viral infection. Proc Natl Acad Sci USA. (2004) 101:16004-9. doi: 10.1073/pnas.0407192101

246. Shin H, Blackburn SD, Blattman JN, Wherry EJ. Viral antigen and extensive division maintain virus-specific CD8 T cells during chronic infection. J Exp Med. (2007) 204:941-9. doi: 10.1084/jem.20061937

247. Pitt JM, Vetizou M, Daillere R, Roberti MP, Yamazaki T, Routy B, et al. Resistance mechanisms to immune-checkpoint blockade in cancer: tumor-intrinsic and -extrinsic factors. Immunity. (2016) 44:1255-69. doi: 10.1016/j.immuni.2016.06.001

248. Vezys V, Masopust D, Kemball CC, Barber DL, O’Mara LA, Larsen CP, et al. Continuous recruitment of naive $\mathrm{T}$ cells contributes to heterogeneity of antiviral CD8 T cells during persistent infection. J Exp Med. (2006) 203:2263-9. doi: 10.1084/jem.20060995

249. Araki K, Youngblood B, Ahmed R. Programmed cell death 1-directed immunotherapy for enhancing T-cell function. Cold Spring Harb Symp Quant Biol. (2013) 78:239-47. doi: 10.1101/sqb.78.019869

250. Duraiswamy J, Ibegbu CC, Masopust D, Miller JD, Araki K, Doho GH, et al. Phenotype, function, and gene expression profiles of programmed death1(hi) CD8 T cells in healthy human adults. J Immunol. (2011) 186:4200-12. doi: 10.4049/jimmunol.1001783

251. Dolfi DV, Mansfield KD, Polley AM, Doyle SA, Freeman GJ, Pircher H, et al. Increased T-bet is associated with senescence of influenza virusspecific CD8 T cells in aged humans. J Leukoc Biol. (2013) 93:825-36. doi: 10.1189/jlb.0912438

252. Ahn E, Araki K, Hashimoto M, Li W, Riley JL, Cheung J, et al. Role of PD1 during effector CD8 T cell differentiation. Proc Natl Acad Sci USA. (2018) 115:4749-54. doi: 10.1073/pnas.1718217115

253. Vigano S, Perreau M, Pantaleo G, Harari A. Positive and negative regulation of cellular immune responses in physiologic conditions and diseases. Clin Dev Immunol. (2012) 2012:485781. doi: 10.1155/2012/485781

254. Blattman JN, Wherry EJ, Ha SJ, van der Most RG, Ahmed R. Impact of epitope escape on PD-1 expression and CD8 T-cell exhaustion during chronic infection. J Virol. (2009) 83:4386-94. doi: 10.1128/JVI.02524-08

255. Streeck H, Brumme ZL, Anastario M, Cohen KW, Jolin JS, Meier A, et al. Antigen load and viral sequence diversification determine the functional profile of HIV-1-specific CD8+ T cells. PLoS Med. (2008) 5:e100. doi: 10.1371/journal.pmed.0050100

256. Kasprowicz V, Kang YH, Lucas M, Schulze zur Wiesch J, Kuntzen T, Fleming $\mathrm{V}$, et al. Hepatitis $\mathrm{C}$ virus (HCV) sequence variation induces an HCVspecific T-cell phenotype analogous to spontaneous resolution. J Virol. (2010) 84:1656-63. doi: 10.1128/JVI.01499-09 
257. Conrad JA, Ramalingam RK, Duncan CB, Smith RM, Wei J, Barnett L, et al. Antiretroviral therapy reduces the magnitude and $\mathrm{T}$ cell receptor repertoire diversity of HIV-specific T cell responses without changing T cell clonotype dominance. J Virol. (2012) 86:4213-21. doi: 10.1128/JVI.06000-11

258. Fuller MJ, Hildeman DA, Sabbaj S, Gaddis DE, Tebo AE, Shang L, et al. Cutting edge: emergence of CD127high functionally competent memory $\mathrm{T}$ cells is compromised by high viral loads and inadequate $\mathrm{T}$ cell help. $J$ Immunol. (2005) 174:5926-30. doi: 10.4049/jimmunol.174.10.5926

259. Wang C, McPherson AJ, Jones RB, Kawamura KS, Lin GH, Lang PA, et al. Loss of the signaling adaptor TRAF1 causes CD8 $+\mathrm{T}$ cell dysregulation during human and murine chronic infection. J Exp Med. (2012) 209:77-91. doi: 10.1084/jem.20110675

260. Ahn E, Youngblood B, Lee J, Lee J, Sarkar S, Ahmed R. Demethylation of the PD-1 promoter is imprinted during the effector phase of CD8 T cell exhaustion. J Virol. (2016) 90:8934-46. doi: 10.1128/JVI.00798-16

261. Butler NS, Moebius J, Pewe LL, Traore B, Doumbo OK, Tygrett LT, et al. Therapeutic blockade of PD-L1 and LAG-3 rapidly clears established blood-stage plasmodium infection. Nat Immunol. (2011) 13:18895. doi: 10.1038/ni.2180

262. Grosso JF, Goldberg MV, Getnet D, Bruno TC, Yen HR, Pyle KJ, et al. Functionally distinct LAG-3 and PD-1 subsets on activated and chronically stimulated CD8 T cells. J Immunol. (2009) 182:6659-69. doi: 10.4049/jimmunol.0804211

263. Wolchok JD, Kluger H, Callahan MK, Postow MA, Rizvi NA, Lesokhin AM, et al. Nivolumab plus ipilimumab in advanced melanoma. $N$ Engl J Med. (2013) 369:122-33. doi: 10.1056/NEJMoa1302369

264. Ngiow SF, Teng MW, Smyth MJ. Prospects for TIM3-targeted antitumor immunotherapy. Cancer Res. (2011) 71:6567-71. doi: 10.1158/0008-5472.CAN-11-1487

265. Ngiow SF, von Scheidt B, Akiba H, Yagita H, Teng MW, Smyth MJ. Anti-TIM3 antibody promotes T cell IFN-gamma-mediated antitumor immunity and suppresses established tumors. Cancer Res. (2011) 71:354051. doi: 10.1158/0008-5472.CAN-11-0096

266. Zhou Q, Munger ME, Veenstra RG, Weigel BJ, Hirashima M, Munn DH, et al. Coexpression of Tim-3 and PD-1 identifies a CD8+ T-cell exhaustion phenotype in mice with disseminated acute myelogenous leukemia. Blood. (2011) 117:4501-10. doi: 10.1182/blood-2010-10-310425

267. Kassu A, Marcus RA, D’Souza MB, Kelly-McKnight EA, Palmer BE. Suppression of HIV replication by antiretroviral therapy reduces TIM-3 expression on HIV-specific CD8 ${ }^{+}$T cells. AIDS Res Hum Retroviruses. (2011) 27:1-3. doi: 10.1089/aid.2010.0156

268. Poonia B, Pauza CD. Levels of CD56+TIM-3- effector CD8 T cells distinguish HIV natural virus suppressors from patients receiving antiretroviral therapy. PLoS ONE. (2014) 9:e88884. doi: 10.1371/journal.pone.0088884

269. Wei SC, Duffy CR, Allison JP. Fundamental mechanisms of immune checkpoint blockade therapy. Cancer Discov. (2018) 8:1069-86. doi: 10.1158/2159-8290.CD-18-0367

270. Wolthers KC, Miedema F. Telomeres and HIV-1 infection: in search of exhaustion. Trends Microbiol. (1998) 6:144-7. doi: 10.1016/S0966-842X(98)01233-5

271. Zhou S, Ou R, Huang L, Price GE, Moskophidis D. Differential tissue-specific regulation of antiviral CD8 + T-cell immune responses during chronic viral infection. J Virol. (2004) 78:3578-600. doi: 10.1128/JVI.78.7.3578-3600.2004

272. Champagne P, Ogg GS, King AS, Knabenhans C, Ellefsen K, Nobile M, et al. Skewed maturation of memory HIV-specific CD8 T lymphocytes. Nature. (2001) 410:106-11. doi: 10.1038/35065118

273. Vigano S, Negron J, Ouyang Z, Rosenberg ES, Walker BD, Lichterfeld $\mathrm{M}$, et al. Prolonged antiretroviral therapy preserves HIV-1-specific CD8 T cells with stem cell-like properties. J Virol. (2015) 89:7829-40. doi: 10.1128/JVI.00789-15

274. Doherty PC. Immune exhaustion: driving virus-specific CD8+ $\mathrm{T}$ cells to death. Trends Microbiol. (1993) 1:207-9. doi: 10.1016/0966-842X(93)90133-C
275. Alter G, Hatzakis G, Tsoukas CM, Pelley K, Rouleau D, LeBlanc R, et al. Longitudinal assessment of changes in HIV-specific effector activity in $\mathrm{HIV}$-infected patients starting highly active antiretroviral therapy in primary infection. J Immunol. (2003) 171:477-88. doi: 10.4049/jimmunol.17 1.1.477

276. Jamieson BD, Yang OO, Hultin L, Hausner MA, Hultin P, Matud J, et al. Epitope escape mutation and decay of human immunodeficiency virus type 1-specific CTL responses. J Immunol. (2003) 171:5372-9. doi: $10.4049 /$ jimmunol.171.10.5372

277. Rajandram R, Bennett NC, Wang Z, Perry-Keene J, Vesey DA, Johnson DW, et al. Patient samples of renal cell carcinoma show reduced expression of TRAF1 compared with normal kidney and functional studies in vitro indicate TRAF1 promotes apoptosis: potential for targeted therapy. Pathology. (2012) 44:453-9. doi: 10.1097/PAT.0b013e3283557748

278. Vezys V, Penaloza-MacMaster P, Barber DL, Ha SJ, Konieczny B, Freeman GJ, et al. 4-1BB signaling synergizes with programmed death ligand 1 blockade to augment CD8 T cell responses during chronic viral infection. J Immunol. (2011) 187:1634-42. doi: 10.4049/jimmunol.1100077

279. Crawford A, Angelosanto JM, Kao C, Doering TA, Odorizzi PM, Barnett BE, et al. Molecular and transcriptional basis of $\mathrm{CD}^{+}{ }^{+} \mathrm{T}$ cell dysfunction during chronic infection. Immunity. (2014) 40:289-302. doi: 10.1016/j.immuni.2014.01.005

280. Mullen AC, Orlando DA, Newman JJ, Loven J, Kumar RM, Bilodeau S, et al. Master transcription factors determine cell-type-specific responses to TGF-beta signaling. Cell. (2011) 147:565-76. doi: 10.1016/j.cell.2011. 08.050

281. Trompouki E, Bowman TV, Lawton LN, Fan ZP, Wu DC, DiBiase A, et al. Lineage regulators direct BMP and Wnt pathways to cell-specific programs during differentiation and regeneration. Cell. (2011) 147:577-89. doi: 10.1016/j.cell.2011.09.044

282. Intlekofer AM, Takemoto N, Kao C, Banerjee A, Schambach F, Northrop $\mathrm{JK}$, et al. Requirement for T-bet in the aberrant differentiation of unhelped memory CD8+ T cells. J Exp Med. (2007) 204:2015-21. doi: 10.1084/jem.20070841

283. Banerjee A, Gordon SM, Intlekofer AM, Paley MA, Mooney EC, Lindsten T, et al. Cutting edge: the transcription factor eomesodermin enables CD8+ T cells to compete for the memory cell niche. J Immunol. (2010) 185:4988-92. doi: 10.4049/jimmunol.1002042

284. Paley MA, Gordon SM, Bikoff EK, Robertson EJ, Wherry EJ, Reiner SL. Technical advance: fluorescent reporter reveals insights into eomesodermin biology in cytotoxic lymphocytes. J Leukoc Biol. (2013) 93:307-15. doi: 10.1189/jlb.0812400

285. Zhou X, Yu S, Zhao DM, Harty JT, Badovinac VP, Xue HH. Differentiation and persistence of memory $\mathrm{CD}^{+} \mathrm{T}$ cells depend on $\mathrm{T}$ cell factor 1 . Immunity. (2010) 33:229-40. doi: 10.1016/j.immuni.2010.08.002

286. Intlekofer AM, Takemoto N, Wherry EJ, Longworth SA, Northrup JT, Palanivel VR, et al. Effector and memory CD8 $+\mathrm{T}$ cell fate coupled by T-bet and eomesodermin. Nat Immunol. (2005) 6:1236-44. doi: 10.1038/n i1268

287. Scharer CD, Barwick BG, Youngblood BA, Ahmed R, Boss JM. Global DNA methylation remodeling accompanies CD8 T cell effector function. $J$ Immunol. (2013) 191:3419-29. doi: 10.4049/jimmunol.1301395

Conflict of Interest: The authors declare that the research was conducted in the absence of any commercial or financial relationships that could be construed as a potential conflict of interest.

Copyright (c) 2020 Vigano, Bobisse, Coukos, Perreau and Harari. This is an openaccess article distributed under the terms of the Creative Commons Attribution License (CC BY). The use, distribution or reproduction in other forums is permitted, provided the original author(s) and the copyright owner(s) are credited and that the original publication in this journal is cited, in accordance with accepted academic practice. No use, distribution or reproduction is permitted which does not comply with these terms. 